\title{
Medical Decision Making for Youth in the Foster Care System
}

\author{
By Zach Strassburger
}

Abstract: Youth in the foster care system often have no one person who is clearly authorized to make medical decisions for them. From a caseworker insisting upon a vaccine to a birth parent refusing permission for psychotropic medication, the evidence supports the argument that who makes these decisions matters for children's rights. The Author reviewed relevant laws and policies, surveyed stakeholders to understand actual practices, then interviewed a subset of these stakeholders to get further details about who gets to decide what care a young person receives. This Article argues that policies should be nuanced but consistent, promoting birth parent involvement and family reunification while acknowledging real timelines.

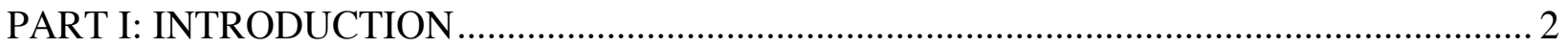

A. Overall Health Care for Young People in the Child Welfare System ................................. 4

B. Mental Health Care for Youth in the Child Welfare System .............................................. 6

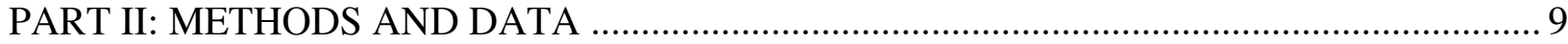

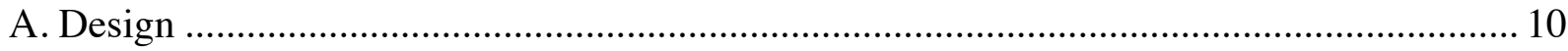

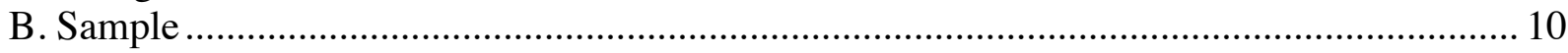

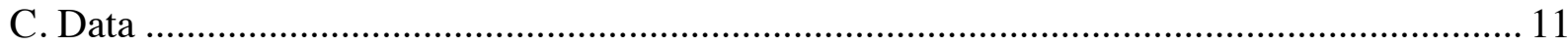

Map 1. Ability to Make Decisions According to Law and Policy ...................................... 14

Map 2. Ability to Make Decisions According to Survey .................................................... 14

Map 3. Combining Law and Survey Responses Yields Contradictions ............................ 15

Map 4. States in which the County or State Can Make Medical Decisions, According to

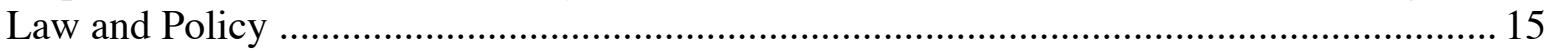

Map 5. Most Common Medical Decision Maker ….......................................................... 15

PART III: EVALUATING POTENTIAL DECISIONMAKERS ........................................... 16

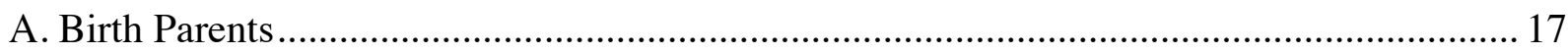

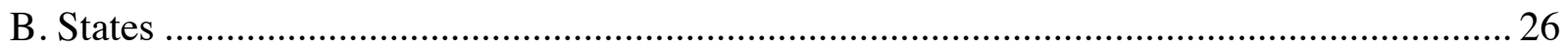

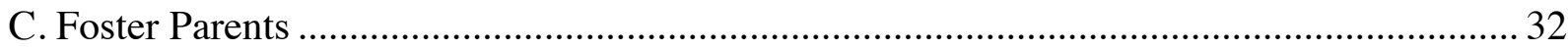

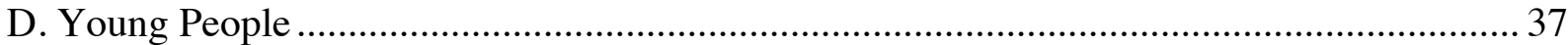

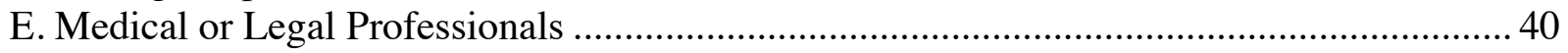

PART IV. CONCLUSIONS AND PROPOSALS ............................................................ 45 


\section{PART I: INTRODUCTION}

Twenty years ago, a federal report drew attention to a national failure to provide children in the foster care system with necessary health services. ${ }^{1}$ Since then, while states have created plans to improve access to health care for youth in the child welfare system, ${ }^{2}$ there has been no corresponding move to ensure that the care given is appropriate or that there is a consistent party making medical decisions for youth in care. My research examined all U.S. states' laws and policies about medical decision making for youth in the foster care system and found that policies vary not only nationally but also county by county. ${ }^{3}$ This Article presents the results of a national survey and follow-up interviews of people affected by these issues. It demonstrates how the lack of clear decision-making authority for who can give authorization for a child to visit a doctor or take a certain medication can cause significant confusion for caretakers, medical providers, and youth.

This Article describes who currently makes the decisions for children in foster care across the United States, analyzes the benefits and drawbacks of each potential medical decision

\footnotetext{
${ }^{1}$ U.S. GEN. ACCT. OFF., GAO-95-114, Foster CARE: HeAlth NEEDS OF MANY YOUNG ChILdREN ARE UNKNOWN AND UNMET 2 (1995), http://www.gao.gov/assets/230/221275.pdf. This Article uses "child," "children," and "youth" all to refer to someone under the age of majority in the state in which he or she lives, most often someone under the age of 18. "Foster care system" means temporary out-of-home care given when a child has been removed from the care of the parents in a dependency proceeding, including foster homes, group homes, and residential treatment centers. See National Adoption Ctr., What is Foster Care http://www .adopt.org/what-foster-care (last visited Feb. 18, 2016).

${ }^{2}$ States have differed in their creation and implementation of these new policies. Pub. L. No. 110-351 (2008); U.S. Gen. ACCT. OfF., GAO-09-26, Foster CARE: STATE Practices FOR AsSessing Health NEEDS, FACILITATING SERVICE DELIVERY, AND MONITORING CHILDREN's CARE 2 (2009); Child and Family Services Improvement and Innovation Act, Pub. L. No. 112-34, § 101(b)(2), 125 Stat. 369 (2011). See Administration for Children and Families, Program Instruction, ACYF-CB-PI-12-05; see also U.S. GEN. ACCT. OfF., GAO-14-362, FOSTER CHILDREN: ADDITIONAL FEDERAL GUIDANCE COULD HELP STATES BETTER PLAN FOR OVERSIGHT OF PSYCHOTROPIC MEDICATIONS ADMINISTERED BY MANAGEDCARE ORGANIZATIONS 20-26 (2014), http://www .gao.gov/assets/670/662777.pdf (describing what five selected states were doing in response to the law mandating coordination and monitoring of psychotropic medication usage).

${ }^{3}$ See Thomas I. Mackie et. al., Psychotropic medication oversight for youth in foster care: A national perspective on state child welfare policy and practice guidelines, 33 CHILD. \& YOUTH SERVS. REV. 2213, 2214 (2011) ("[T]he ability to benefit from state experimentation may be compromised due to limited empirical investigation into aspects of state variation and knowledge translation between states.").
} 
maker in the life of a child in the welfare system, and makes an argument for who should have this power. In some states, birth parents retain rights to make medical decisions for their children despite substantiated charges of abuse and neglect. ${ }^{4}$ In other states, child protective service caseworkers have the ability to make these decisions as representatives of the state. In yet other states, foster parents get these rights as the temporary caretaker for the child and the ones who have greatest knowledge of the child's current behavior. Family courts occasionally appoint independent lawyers as medical decision makers. ${ }^{5}$ Finally, youth themselves are able to make some decisions, and in practice, doctors have significant influence on many medical decisions. The localized nature of child welfare services and the presence of few national regulations gives states flexibility, but it also creates a bewildering array of policies and practices. ${ }^{6}$

Part I of this paper introduces the current crisis of physical and mental health care for youth in the child welfare system. Part II discusses the survey results as to who currently makes decisions for children in foster care according to state laws and in practice. Part III addresses the benefits and drawbacks of each possible decision maker having authority to make decisions. Part IV provides recommendations on how to improve the existing systems.

\footnotetext{
4 "Birth parent" is commonly used, along with "biological parent," to refer to the parents against whom charges are filed and from whom a child is removed in a dependency case. In reality, children can be removed from any primary caretaker, including a grandparent or an adoptive parent. See infra notes and accompanying charts. Language in statutes and regulations varies, and the location of the directive language is inconsistent between states. However, one clear example can be found in Delaware. The document states, "A licensee shall obtain written authorization for both routine medical care and nonroutine or emergency care immediately upon initial placement, Authorization shall be either from a birth parent, guardian, or by court order." CDR 9-200-201 (2015), “Authorizaton for Medical Care.” Iowa puts the information in its foster parent handbook, telling foster parents, "You do not have the authority to consent to medical care. Only the child's parent or guardian may consent to such care, except that the legal custodian may consent to emergency care." Foster Parent Handbook, Iowa Dep't of Hum. Serv's 44 Comm. 33 (2005), https://dhs.iowa.gov/sites/default/files/comm33.pdf (last visited Oct. 24, 2016).

${ }^{5}$ See PA. R. Juv. Ct.. P. § 1145; In re J.A., 107 A.3d 799, 806-07 (2015 Pa. Super. 3).(describing the guardianship unit at KidsVoice in Pittsburgh, PA).

${ }^{6}$ Laurel K. Leslie et. al., Investigating Geographic Variation in Use of Psychotropic Medications Among Youth in Child Welfare, 35 CHILD ABUSE \& NEGLECT 333, 334 (2011).
} 


\section{A. Overall Health Care for Young People in the Child Welfare System}

Young people in the child welfare system have unmet specialized healthcare needs. The American Academy of Pediatrics describes young people in the child welfare system as a "uniquely disadvantaged group." ${ }^{, 7}$ Specifically they found:

Prior to foster care, the vast majority lived with families devastated by substance abuse, mental health disorders, poor education, unemployment, violence, lack of parenting skills, and involvement with the criminal justice system. High rates of premature birth, prenatal drug and alcohol exposure, and postnatal abuse and neglect contribute to the extremely poor health status of children and adolescents entering foster care. In addition, health care prior to foster care placement often is inadequate, meaning that children and adolescents entering foster care have multiple unmet health care needs, far exceeding even those of other children who are poor. Once children and adolescents are placed in foster care, health care often is sporadic, crisis-oriented, and poorly accessible. The high mobility of the foster care population among placements, ongoing issues of separation and loss, and the complexities of the foster care system exacerbate these problems. ${ }^{8}$

Almost half of children entering Chicago's foster care system and over 90\% of children entering Baltimore's had an unmet medical need. ${ }^{9}$ Children in foster care are seven times more likely to experience developmental delays than children who are not in foster care. ${ }^{10}$ In addition it is very difficult for most children in the child welfare system to access clinical trials. ${ }^{11}$ With such high health needs, these young people require seamless care coordination, but unfortunately, that does not happen.

Youth in the child welfare system face many limits in accessing health care. The vast majority of children in foster care have public health insurance, and many of these children

\footnotetext{
${ }^{7}$ TASK ForCE ON HEALTH CARE FOR CHILDREN IN FOSTER CARE, AMERICAN ACADEMY OF PEDIATRICS, Fostering HEALTH: HEALTH CARE FOR CHILDREN AND ADOLESCENTS IN FOSTER CARE, $2^{\text {nd }}$ ed., 1 (2005) [hereinafter "FOSTERING HEALTH"]

${ }^{8} I d$.

${ }^{9}$ Robin Chernoff et al., Assessing the health status of children entering foster care. 93 PEDIATRICS 594, 594 (1994).

${ }^{10}$ Sandra Stukes Chipungu \& Tricia B. Bent-Goodley, Meeting the Challenges of Contemporary Foster Care, 14 FUTURE CHILD 75, 85 (2004).

${ }^{11}$ Sheryl L. Buske, Foster Children and Pediatric Clinical Trials: Access Without Protection Is Not Enough, 14 VA. J. SOC. POL'Y \& L. 253, 295 (2007).
} 
change insurance upon entry and exit from care. One example of the difficulties faced by youths in the child welfare system are changes in insurance coverage. ${ }^{12}$ Finding mental health providers who accept public health insurance, especially in rural areas, is also very difficult. ${ }^{13}$ One interviewee stated they were required to travel several counties away for autism assessments. ${ }^{14}$ Scheduling and transportation also present difficulties, as young people in the child welfare system have many appointments with different people related to their court cases, their individual health or education needs, and family visits. ${ }^{15}$ Once children are in the child welfare system, they receive care disproportionately often at emergency departments rather than with providers who know their histories and needs. ${ }^{16}$ Specifically, children in the child welfare system receive more emergency department care than other children their age, but less non-emergency care, This suggests that children in the child welfare system have less access to non-emegency care than non-foster kids of the same age. ${ }^{17}$

Another complication faced by young people in the child welfare system is frequent placement changes. This leads to treatment discontinuity, as well as "the use of increasing numbers and combinations of medications, to their inappropriate administration, and even to

\footnotetext{
${ }^{12}$ Youth leaving foster care, whether aging out or returning to their families of origin, often lose health insurance coverage even when they are still financially or categorically eligible. See Margo Rosenbach et. al., Children in Foster Care: Challenges in Meeting Their Health Care Needs Through Medicaid, in HEALTH AND WELFARE FOR FAMILIES IN THE $21^{\text {sT }}$ CENTURY 198-99 (Helen M. Wallace ed., 2003).

${ }^{13}$ Telephone Interview with A.L., foster parent in New Jersey (Aug. 10, 2015). ${ }^{14} I d$.

${ }^{15}$ See, e.g., "MimiTammy," The Never-Ending Foster Care Appointments, Part One, FOSTER2FOREVER (July 11, 2011), http://foster2forever.com/2011/07/the-never-ending-foster-care-appointments-partone.html (detailing the scheduling difficulties of all of the appointments needed for one child in foster care).

${ }^{16}$ Whereas one might expect that health emergencies could create a need for a placement change, $75 \%$ of emergency visits within three weeks of a placement change occur in the days immediately following that placement change, not preceding it. David Rubin et. al., Placement changes and emergency department visits in the first year of foster care, 114 PEDIATRICS 6 (2004).

${ }^{17} I d$.
} 
abrupt discontinuation." ${ }^{18}$ Young people face the initial separation from family but then also separations from individuals involved in their treatments, shifting placements, and transitions in caregivers and state workers. ${ }^{19}$ Trauma and separation are defining features of foster care, and how we deliver medical care to young people in the child welfare system accentuates that trauma rather than alleviate it.

\section{B. Mental Health Care for Youth in the Child Welfare System}

Young people in the child welfare system suffer from emotional problems at far higher rates than children not in the child welfare system. While only twenty percent of youth overall are believed to have clinically significant emotional or behavioral problems,${ }^{20} 47.9$ percent of youth in the child welfare system suffer from emotional or behavioral problems. ${ }^{21}$ Fifty percent of all Medicaid psychiatric visits in California were for children in foster care, even though this group represented less than five percent of California's Medicaid enrollees.$^{22}$ Only $0.9 \%$ of children are survivors of substantiated cases of abuse and neglect, but these young people are seriously overrepresented in mental health placements. ${ }^{23}$ In 1997 , over twenty percent of children admitted to inpatient psychiatric units and almost half of children admitted to residential

\footnotetext{
${ }^{18}$ Robin Mekonnen et. al., Achieving Better Health Care Outcomes for Children in Foster Care, 56 PEDIATRICS CliniCs OF NORTH AM. 405, 408 (2009).

${ }^{19}$ David L. DiGiuseppe \& Dimitri A. Christakis, Continuity of care for children in foster care, 111 PEDIATRICS e208, e208 (2003); Sigrid James, Why do foster care placements disrupt? An investigation of reasons for placement change in foster care. 78 SOC. SERV. REV. 601 (2004).

${ }^{20}$ NeW FreEdom COMMISSION ON MENTAL HEALTH, SMA-03-3832, ACHIEVING THE PROMISE: TRANSFORMing MENTAL HEALTH CARE IN AMERICA 60 (2003), http://govinfo.library.unt.edu/mentalhealthcommission/reports/FinalReport/downloads/FinalReport.pdf

${ }^{21}$ BJ Burns et. al., Mental health need and access to mental health services by youths involved with child welfare: a national survey, 43 J. AM. ACAD. CHILD \& ADOLESCENT PSYCHIATRY 960 (2004).

${ }^{22}$ Neal Halfon et. al., Mental health service utilization by children in foster care in California. 89 PEDIATRICS 1238 (1992)

${ }^{23}$ U.S. DeP'T HEALTh \& HUM. SeRvs., Child MaltreatMent ii (2013)

http://www.acf.hhs.gov/sites/default/files/cb/cm2013.pdf
} 
treatment centers for emotionally disturbed children had been victims of child abuse or neglect. ${ }^{24}$ Mental health needs are high for youth in the child welfare system, so it is important that these youth receive appropriate care.

Youth in the foster care system are more likely to be receiving any psychotropic (mental health) medications and are more likely to be on multiple psychotropic medications than youth outside the system. Jack Levine, former president of the Center for Florida's Children, said, “An assumption I thought we made was that care [for youth in the foster care system] would never be appreciably different, in terms of medical carefulness and appropriateness of prescriptions, than everyone else's children." ${ }^{25}$ He concluded that unfortunately, there was "a remarkable difference in how these children are being looked at, diagnosed, and treated." ${ }^{26}$ Eighteen percent of youth in the foster care system in the United States received psychotropic prescriptions, over three times the rate of youth overall. ${ }^{27}$ Around seventy percent of those receiving medications were receiving multiple psychotropic medications at a time, as compared to twenty percent of youth not in care ${ }^{28}$ Children in the child welfare system are also more likely to live in long-term psychiatric facilities. Half of the young people institutionalized in mental health facilities and other residential treatment facilities came to those facilities via the child welfare system, according to

\footnotetext{
${ }^{24}$ Kathleen J. Pottick et al., Children and Adolescents Admitted to Specialty Mental Health Care Programs in the United States, 1986 and 1997, in Mental Health, United States, 2002, at 314, 322 (Ronald W. Manderscheid \& Marilyn J. Henderson eds., 2004), Table 1.

${ }^{25}$ Carol Marbin Miller, Advocates Alarmed By Drugs Used for Kids: Medicaid Children Under 6 at Issue, MIAMI HERALD, May 7, 2001, available at http://www.vachss.com/help_text/archive/advocates_alarmed.html (last accessed Nov 15, 2015). ${ }^{26} I d$.

${ }^{27}$ U.S. Gen. ACCT. OfF., GAO-13-15, ChILDREN's MENTAl HEAlth: CONCERnS REMAIN ABOUt APPROPRIATE SERVICES FOR CHILDREN IN MEDICAID AND FOSTER CARE 17, 25 (2012), http://www.gao.gov/assets/660/650716.pdf; Bonnie T. Zima et. al., Psychotropic Medication Use Among Children in Foster Care: Relationship to Severe Psychiatric Disorders, 89 AM. J. PUB. HEALTH 1732, 1734 (1999).

${ }^{28}$ Daniel Safer et. al., Concomitant psychotropic medication for youths, 160 AM. J. PSYCHIATRY 438, 438 (2003); Julie Magno Zito, et. al. Psychotropic medication patterns among youth in foster care, 121 PEDIATRICS e157, e161 (2008).
} 
one GAO report. ${ }^{29}$ The report notes, “[C]hildren locked up in long-term treatment facilities are ioften mistreated, overmedicated, abused, and held longer than therapeutically warranted." ${ }^{30}$ In Parham v.J.R., Chief Justice Burger wrote that wards of the state may be "lost in the shuffle" after being admitted to a psychiatric facility, and may have their stays extended beyond medical necessity due to the difficulty of finding a foster home for the young person; studies have borne out this prediction. ${ }^{31}$ These youths are held away from the rest of society and prevented from establishing normal lives. ${ }^{32}$

Psychotropic medication usage is not spread evenly across age, race or ethnic groups, placement type, or geographic region. "Youth with aggressive behavior, male gender, severe emotional illness, and disabling social maladjustment are most likely to receive concomitant psychotropic medication." ${ }^{33}$ Psychotropic medications are often used to sedate or otherwise chemically restrain a hyperactive child rather than in true emergencies or following evidencebased practices. ${ }^{34}$ The strongest predictor of whether a child in Connecticut would receive psychotropic medications was whether that child was in the custody of the state.$^{35}$ Children in state custody in a Georgia juvenile prison received medications without diagnoses or psychiatric

${ }^{29}$ U.S. GEN. ACCT. OFF., GAO-PEMD-85-2, RESIDENTIAL CARE: PATTERNS OF CHILD PLACEMENT IN THREE STATES vi (1985), http://www.gao.gov/assets/150/143109.pdf

${ }^{30}$ Bernard P. Perlmutter \& Carolyn S. Salisbury, "Please Let Me Be Heard:" The Right of a Florida Foster Child to Due Process Prior to Being Committed to a Long-Term, Locked Psychiatric Institution, 25 Nova L. REV. 725, 732 (2001).

${ }^{31} I d$. at 733; Parham v. J.R., 442 U.S. 584, 619 (1979)

${ }^{32}$ Id.; See, e.g., Gary B. Melton, ET Al., No Place to Go: The Civil Commitment of Minors 33-38 (U. of Nebraska Press, 1998) (discussing the limited options for children who need mental health care); Ira M. Schwartz, Rethinking the Best Interests of the Child, in JUSTICE FOR JUVENILES 131-48 (Lexington Books 1989) (characterizing these unnecessary hospitalizations as "being abused at better prices"); Lois A. Weithorn, Note, Mental Hospitalization of Troublesome Youth: An Analysis of Skyrocketing Admission Rates, 40 STAN. L. REV. 773, 788-91 (1988).

${ }^{33}$ Safer et. al., supra note 28, at 438.

${ }^{34}$ Matthew M. Cummings, Sedating Forgotten Children: How Unnecessary Psychotropic Medication Endangers Foster Children's Rights \& Health, 32 B.C. J.L. \& SOC. JUST. 357, 361, 378 (2012); U.S. GEN. ACCT. OFF., GAO-14-362, supra note 2, at 10; Burton, supra note 35, at 472.

${ }^{35}$ Angela Olivia Burton, "They Use it Like Candy": How the Prescription of Psychotropic Drugs to StateInvolved Children Violates International Law, 35 BROOK. J. INT’L L. 453, 476 (2010). 
evaluations, with no contact between psychiatrists and medical or direct care staff, and starting dosages that were up to five or six times traditionally acceptable starting dosages. ${ }^{36}$

Without clear lines of authority for who should consent to and monitor these complex medication patterns, children are at risk. Almost half of all medications used for the treatment of emotional or behavioral disturbances in children are off-label, which means they have no approved use for patients under age eighteen. ${ }^{37}$ There are few approved drugs for children under the age of eighteen and so some off-label usage may be appropriate. However, these prescribing patterns are highly concerning both because of the high rates of usage and because children who have someone other than parents making their healthcare decisions are the most likely to be receiving these medications.

\section{PART II: METHODS AND DATA}

Allegheny County, Pennylvania, had a system of appointing attorneys as medical decision makers for young people in the foster care system between aproximately 2006 and 2015. ${ }^{38}$ In 2015, the Pennsylvania Supreme Court ruled that attorneys could no longer hold those positions, but stated that anyone who had physical or legal custody of the child could make the medical decisions instead. This study set out to determine who was making these decisions for youth across the United States, and to attempt to understand who was doing it best.

\footnotetext{
${ }^{36} \mathrm{Id}$. at 511-512.

${ }^{37}$ Michael W. Naylor et. al., Psychotropic Medication Management for Youth in State Care: Consent, Oversight, \& Policy Considerations, 86 CHILD WELFARE 175, 178 (2007).

${ }^{38}$ See In re J.A., 107 A.3d 799, 806-07 (2015 Pa. Super. 3). The Author of this Article served as a medical and educational decision maker in Allegheny County, Pennsylvania between September 2012 and August 2014.
} 


\section{A. Design}

This was a three-part study involving a national survey, interviews, and legal research. Its goal was to understand how medical decisions were being made for youths in the child welfare system. This study looked for norms and outliers to determine if there were jurisdictions in which survey respondents, interviewees, or published materials reported either particular satisfaction or concerns with the status quo.

First, data was gathered concerning laws and policies related to medical decision making for youth in the child welfare system of each state and Washington, D.C. These sources ranged from formal statues, case law, and regulations to less formal sources like foster parent handbooks and websites. These sources were analyzed to determine who, according to these written sources, could make medical decisions for youth in the child welfare system. A map showing the results of this research can be seen on page 14 of this paper.

Next, an information-gathering survey was distributed to find out what people thought the laws were in their states in the summer of 2015. This anecdotal evidence demonstrated that many people simply follow the norms for their areas without ever knowing the laws in their jurisdictions. A map showing the results of this research also can be seen on page 14 of this paper.

Follow-up interviews were conducted with survey respondents who had expressed interest in sharing more information about access to medical care for young people in care in their jurisdictions. The Winona State University Institutional Review Board approved the survey and follow-up interview plans.

\section{B. Sample}

Respondents to the survey came from outreach via e-mail listserves, Facebook posts and groups, and direct outreach to almost 1,200 email addresses found online on web sites related to 
foster care, Court Appointed Special Advocates, birth parent rights, homeless youth, guardians ad litem, social services, and other related topics. One hundred and four people responded to this survey, with respondents identifying themselves as foster parents, attorneys, caseworkers, administrators, medical professionals, and others who had familiarity with systems of medical decision making for youth in care. Respondents came from 49 states and Washington, D.C.

Seventeen survey respondents underwent qualitative follow-up interviews. Most of these interviews were conducted by telephone; two were in person. Interviews ranged in length from thirty minutes to over two hours, depending on the desire of the interviewee. Of the survey respondents interviewed, there were seven foster parents, two attorneys, five child welfare administrators or caseworkers, and two medical doctors. One foster parent was also a clinician who worked with children with autism in the foster care system.

\section{Data}

Examining state statutes, regulations, and policies showed that in most states, birth parents have at least some authority to make medical decisions for their children until their rights are terminated. This authority, however, is often limited to signing blanket consent forms, making decisions on "extraordinary" care, or only decisions pertaining to psychotropic medications.

Forty-five states legally authorized birth parents to make at least some decisions for their biological children who are in foster care at the same time as survey respondents from those states claimed that little effort went to keeping in touch with birth parents..$^{39}$ In thirty-seven

\footnotetext{
${ }^{39}$ All survey data is from Zach Strassburger, Medical Decision Making for Youth in Care. Survey. Qualtrics, https://winona.az1.qualtrics.com/SE/?SID=SV cu2wrd9lnAaYBhz. Web, 2015 [hereinafter Strassburger, 2015]..All states except Arkansas, Illinois, Louisiana, Nebraska, and Texas authorize the birth parent to make some decisions. Texas can legally appoint the birth parent, but the default is the foster parent. See Appendix I for survey questions and Appendix II for applicable laws and policies.
} 
states, someone other than the birth parent was the most common medical decision maker. ${ }^{40}$

Every state allowed state agents, usually caseworkers or their supervisors, to make at least some medical decisions, and in twenty-two states, the state was the most frequent medical decision maker. $^{41}$

While only half of the states' laws and policies give authority to foster parents to make medical decisions, responses to my survey indicated that in practice, foster parents make decisions in far more states. Specifically, for eight states, both the written law and survey responses agreed that foster parents could not make medical decisions. ${ }^{42}$ Sixteen states had contradictory responses in which either the state's law or policy said yes and the survey responses said no, or survey responses said yes when the state's laws indicated that foster parents could not make medical decisions. ${ }^{43}$ For twenty-six states, both law and survey responses agreed that foster parents did have the authority to make at least some medical decisions. ${ }^{44}$ Washington State is an example of contradictory written laws and survey responses. Washington does a far more thorough job than most states of explaining who can make medical decisions on behalf of youths in foster care. For example, Washington's foster care manual states:

${ }^{40}$ Only in Alaska, Idaho, Iowa, Michigan, Minnesota, Nevada, New Hampshire, New York, Rhode Island, and Wisconsin was the birthparent the most common decision maker. See Appendix II for applicable laws and policies.

${ }^{41}$ Alabama, Arkansas, Colorado, Connecticut, Georgia, Hawaii, Indiana, Illinois, Kentucky, Maine, Massachusetts, Mississippi, Missouri, Nebraska, North Dakota, Oregon, South Dakota, Utah, Vermont, Virginia, West Virginia, and Wyoming. See Appendix II for applicable laws and policies.

${ }^{42}$ Alabama, Alaska, Connecticut; Hawaii, Idaho, Massachusetts, Montana, and Tennessee. See Appendix II for applicable laws and policies.

${ }^{43}$ SEE COMMENT ABOVE

Yes in law; No in practice: Maine, Maryland, and Nebraska. No in law; Yes in practice:

Arkansas, Delaware, Illinois, Iowa, Kentucky (law says emergency only, survey says general care), Michigan, Minnesota, North Carolina, Rhode Island, South Carolina, South Dakota, Utah, Washington state, and Washington, DC. See Appendix II for applicable laws and policies.

${ }^{44}$ Arizona, California, Colorado, Florida, Georgia, Indiana, Kansas, Louisiana, Mississippi, Missouri, Nevada, New Jersey, New Hampshire, New Mexico, New York, North Dakota, Ohio, Oklahoma, Oregon, Pennsylvania, Texas, Vermont, Virginia, West Virginia, Wisconsin, and Wyoming. See Appendix II for applicable laws and policies. 
"No changes to a child's medication shall be made without written consent from a physician, child's social worker, and other designee (i.e., biological parent). 'PRN' or 'as-needed' medications may be dispensed according to the guidelines/prescription/standing orders of the child's physician." 45

Yet while Washington State provides an example of the foster parent not being permitted by law to make medical decisions, in practice survey respondents in Washington reported that foster parents act as the most common medical decision maker in the state. A social worker from Washington State selected the checkbox that foster parents make most medical decisions, and then wrote, "Most often they will send notes or otherwise communicate through a social worker [regarding] minor medical issues."46

The maps below illustrate the law and survey results. While it is impossible to know just how much decision making is being done by each party in states that allow for multiple decision makers, Map 5 shows who out of those options is the most common decision maker. The maps also show that the state or county has the legal authority to make decisions in every state, though it does not always choose to use that power.

\footnotetext{
${ }^{45}$ Service Alternatives, Foster CARE MANUal 13 (May 2014), http://www.servalt.com/wpcontent/uploads/2014/11/2014-foster-care-manual2.pdf (last visited Mar. 5, 2016).

${ }^{46}$ Survey respondent from Washington, in Zach Strassburger, Medical Decision Making for Youth in Care. Survey. Qualtrics, https://winona.az1.qualtrics.com/SE/?SID=SV cu2wrd91nAaYBhz. Web, June $1,2015,17: 15: 39$.
} 
Map 1. Ability to Make Decisions According to Law and Policy

Who can make decisions based on law and policy?

- $\mathrm{BP}, \mathrm{FP}, \mathrm{a}$ State

- FP \& State

- BP a State

- State only
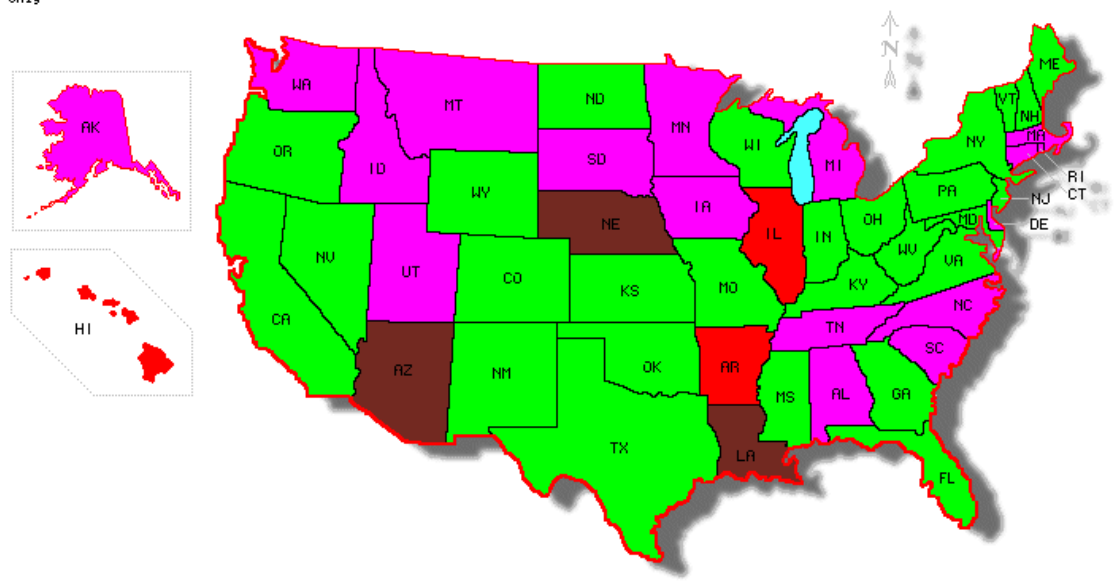

Map 2. Ability to Make Decisions According to Survey

Who can make decisions based on survey?

- $-B P$ \& $F P$

- BP, FP, a state

- FP a state

- BP a state

- FP only
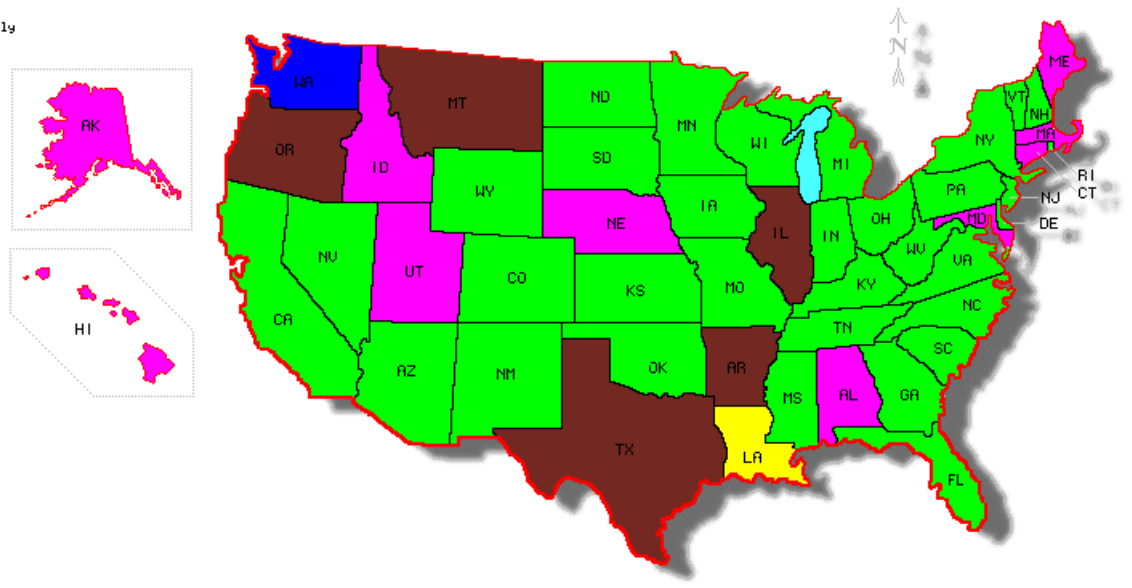

Source: diymopenent (c) 
Map 3. Combining Law and Survey Responses Yields Contradictions
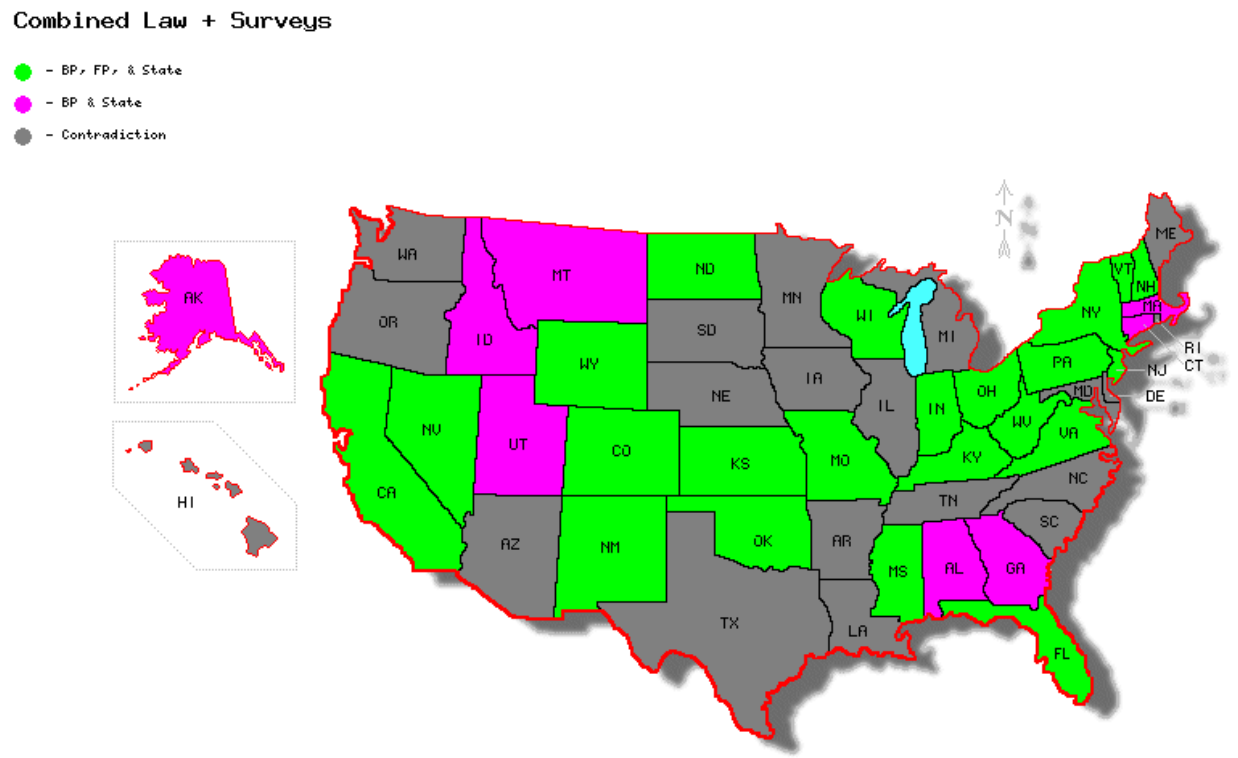

Map 4. States in which the County or State Can Make Medical Decisions, According to Law and Policy

County or State Can Make Medical Decisions

- Ves

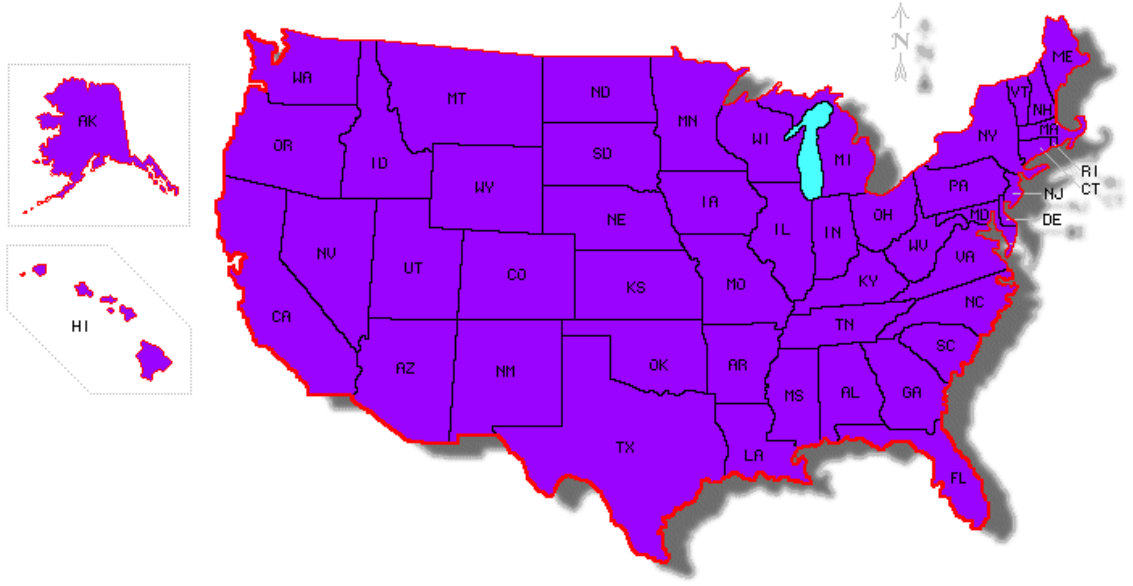

Map 5. Most Common Medical Decision Maker 


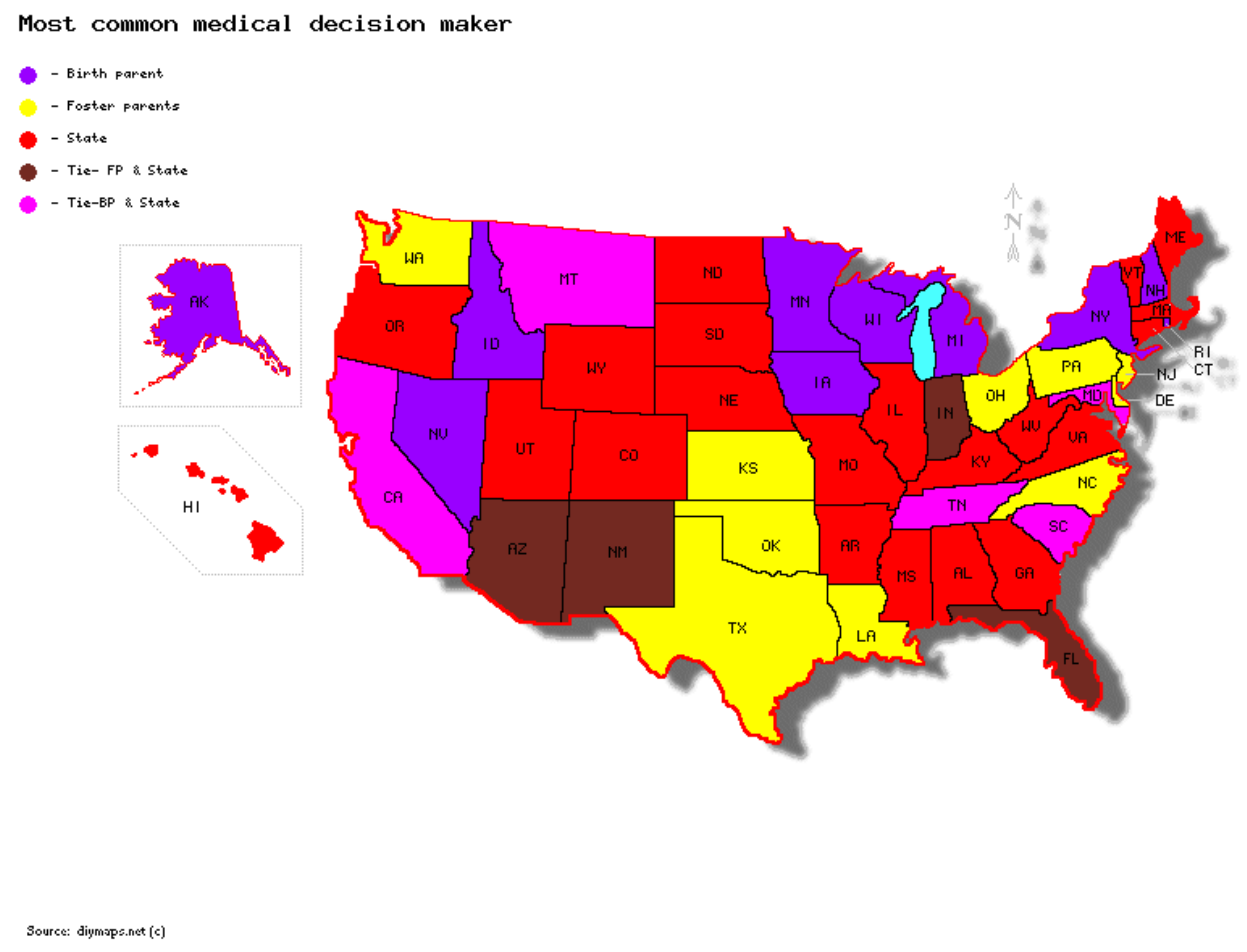

\section{PART III: EVALUATING POTENTIAL DECISIONMAKERS}

This section examines rationales and highlights interview findings in favor of and against the most common potential decision makers: birth parents; the state (including judges, child welfare supervisors and state-level officials, and caseworkers); foster parents; young people themselves; and legal or medical professionals. The various adults in the life of a child in the foster care system all have different backgrounds and vested interests. ${ }^{47}$ To appoint any one of them as medical decision maker for a child presents both benefits and drawbacks. Some jurisdictions assign the decision-making along lines of custody; others split decision making among different parties depending upon the types of medical decisions need to be made.

\footnotetext{
${ }^{47}$ Jeffrey Longhofer et. al., Foster youth and psychotropic treatment: Where next? 33 CHILD. \& YOUTH SERVS. REV. 395, 398-99 (2011).
} 


\section{A. Birth Parents}

Parents with custody of their children are considered to have natural legal rights, including medical decision making rights, over their children. ${ }^{48} \mathrm{~A}$ parent is financially responsible for the necessary debt incurred by a minor child, and the person paying for care generally gets to make the decisions about it. ${ }^{49}$ When children are removed from their biological parent's home but the biological parents' rights have not been terminated, the right or responsibility for medical decisions often shifts away from the parents to someone else even though birth parents are often still paying child support. ${ }^{50}$ The state now has physical custody, and may have legal custody as well. Legal custody means decision-making power; some states explicitly note that when a child is committed to the Department of Health and Social Services, "a relationship of legal custody exists." ${ }^{51}$ Some states retain parental rights for medical decisionmaking in law, but in practice the birth parents do not get to make the decisions about their children's care. ${ }^{52}$ Even when birth parents retain medical decision making rights after children

${ }^{48}$ See Lois A. Weithorn, Envisioning Second-Order Change in America's Responses to Troubled \& Troublesome Youth, 33 HOFSTRA L. REV. 1305, 1394 (2005) (finding that for the most part, parents are permitted to make even "bad" medical decisions on behalf of their children unless the situation is lifethreatening). See also Elizabeth J. Sher, Note, Choosing for Children: Adjudicating Medical Care Disputes Between Parents \& the State, 58 N.Y.U.L. REV. 157, 163-66 (1983) (analyzing how courts in different jurisdictions vary in their willingness to intervene in an otherwise functional family, and noting that the standard for intervention can be as high as life-or-death).

${ }^{49}$ Robert Bennett, Allocation of Child Medical Care Decision-Making Authority: A Suggested Interest Analysis, 62 VA. L. REV. 285, 288 (1976); Carol Sanger \& Eleanor Willemsen. Minor Changes: Emancipating Children in Modern Times, 25 U. MICH. J.L. REFORM 239, 241 (1991-1992); Karol Williams, The Doctrine of Necessaries: Contemporary Application As a Support Remedy, 19 Stetson L. REV. 661, 661 (1989-1990).

${ }^{50}$ Child Support Servs. Division, Changes in Custody,, DC.GOv, http://cssd.dc.gov/page/changes-custody (last visited October 20,2015).

${ }^{51}$ ALASKA STAT. $§ 47.05 .065$ (a).

${ }^{52}$ Wisconsin is an example of a state in which parents legally maintain the right to consent to their biological children's health care, but in practice, foster parents make the decisions. This is managed through the use of routine medical authorization forms, which biological parents are asked to sign as soon as their children enter care. See Wis. Stat. Ann. § 48.02; Wis. Adm. Code DCF 56.09. A copy of the form biological parents are asked to sign can be found at Dep't of Children \& Families, Authorization to Consent to Medical Treatment, Division of Milwaukee Child Protective Servs., http://dcf.wisconsin.gov/forms/pdf/2503.pdf (last visited Oct 22, 2016). 
are removed from their custody, the birth parents lose those rights in all cases before or at the point at which the parents' rights are fully terminated and the children deemed legal orphans. ${ }^{53}$

Decisions about parents' medical decision making are sometimes made by statute, applying to all children in the foster care system, and other times are judicially determined in individual cases. There is no uniform national standard for determining when a state may interfere in a parent's treatment decision. ${ }^{54}$ This gives a great deal of discretion to a judge and might be affected by the quality of the parents' legal representation. Joseph Goldstein wrote that the law should give preference to parents, "hold[ing] in check judges or doctors who may be tempted to use the power of the state to impose their personal preferences." 55 The personal preferences of the judges or doctors can be affected by the vast differences in race and ethnicity, socio-economic class, and level of education between the parents and the judge or the parents and the doctors when parents have been brought before a court on charges of neglect. ${ }^{56}$

Parents who want to make decisions about their children's lives must advocate vigorously. Decisions about who will have medical decision making rights can involve religious, political, or scientific beliefs about what medical treatments are appropriate as much they denote who is best able to represent the child's interests. ${ }^{57}$ State workers or agencies initiate court proceedings when a state worker or agency representative is frustrated at a parent's failure to

\footnotetext{
${ }^{53}$ Jason M. Merrill, Falling Through the Cracks: Distinguishing Parental Rights from Parental Obligations in Cases Involving Termination of the Parent-Child Relationship, 11 J.L. \& FAM. STUD. 203, 209 (2008), available at http://www.epubs.utah.edu/index.php/jlfs/article/viewFile/94/84 (last visited October 20, 2015).

${ }^{54}$ Kimberly M. Mutcherson, No Way to Treat a Woman: Creating an Appropriate Standard for Resolving Medical Treatment Disputes Involving HIV-Positive Children, 25 HARV. WOMEN'S L.J. 221, 249 (2002).

${ }^{55}$ Joseph Goldstein, Medical Care for the Child at Risk: On State Supervention of Parental Autonomy, 86 YALE L.J. 645, 664 (1977).

${ }^{56}$ Annette R. Appell, Protecting Children or Punishing Mothers: Gender, Race, and Class in the Child Protection System, 48 S.C. L. REV. 577, 584-85 (1997).

${ }^{57}$ Naomi Shavin, Disagree with Doctors' Diagnosis of Your Kid and You Might Get Arrested, NEW REPUBLIC, Sept 8, 2014, at http://www.newrepublic.com/article/119366/medical-neglect-what-happenswhen-parents-and-doctors-disagree (last accessed Nov. 3, 2015).
} 
cooperate.$^{58}$ Often, this desired "cooperation" is coded language for the birth parent doing whatever the social worker wants her to do.$^{59}$ In many cases, the parent is pushed through a demeaning process is which there is poor communication and little respect. Often the caseworker only has to threaten to go to court in order to enforce a medical recommendation set forth by someone else in the child's case. ${ }^{60}$ Birth parents rarely contest these decisions in court, which in turn leads to these conflicts going unnoticed by the system. ${ }^{61}$ Similarly, some doctors do not want to interact with birth parents; birth parents have few resources to counter this animosity. A New York foster parent reported seeing a doctor call security on a birth parent who was doing nothing wrong. ${ }^{62}$ Contrary to state regulations, the doctor insisted that the birth father should not be at the appointment at all because the children had been removed from his care. ${ }^{63}$ A child welfare agency supervisor in Idaho agreed, saying that some doctors are "quite harsh" on birth parents, “picking on everything the birth parents do, calling the prosecutor's office, [and] calling on children to be removed from the home. ${ }^{, 64}$ Birth parents who persist in attending appointments are those who are most committed to reunification, suggested the supervisor, because those who are less committed are dissuaded by the poor treatment they receive. ${ }^{65}$

As a policy matter, it is important to involve birth parents in medical decision making in order to honor and protect that family unit and to encourage reunification. Medical decisions are representations of culture, from male Jewish babies being circumcised to Jehovah's witnesses

\footnotetext{
${ }^{58}$ Amy Sinden, “Why Won't Mom Cooperate?": A Critique of Informality in Child Welfare Proceedings, 11 YALE J.L. \& FEMINISM 339, 385 n.194 (1999).

${ }^{59} \mathrm{Id}$. at 354 ("Where there is disagreement between the parties, it is the mother, not the social worker, who is labeled 'uncooperative,' and therefore blamed for creating conflict.").

${ }^{60}$ Telephone Interview with A.L., foster parent in New Jersey (Aug. 10, 2015).

${ }^{61} \mathrm{Id}$.

${ }^{62}$ Telephone Interview with S.A., foster parent in New York (Aug. 5, 2015).

${ }^{63} I d$.

${ }^{64}$ Telephone Interview with K.N., child welfare agency supervisor in Idaho (Aug. 10, 2015). ${ }^{65} \mathrm{Id}$.
} 
avoiding blood transfusions. Even when a finding of abuse or neglect has been made, the birth parent may still be the best potential medical decision maker for his or her child. According to the Adoption and Safe Families Act, the first role of the child welfare system should be to support families such that children do not need to be removed, and the second is to make it possible for the child to return home. ${ }^{66}$ Even the children involved in the three percent of cases that come into the system for parental medical neglect may still have a parent who can be a good medical decision maker. ${ }^{67}$ One interviewee shared a story about the birth mother of one of her foster children. The birth mother was accused of medical neglect after failing to get her child an important specialized treatment. ${ }^{68}$ Child welfare services provided translation into Spanish, but it turned out that the birth mother actually spoke an indigenous language as her primary language and only a little Spanish. ${ }^{69}$ The failure to provide the birth mother with translation services into her native language meant she failed to understand the complexity of her child's medical situation. ${ }^{70}$ After the birth mother finally received translation services in her native language, she made positive decisions for her child. ${ }^{71}$

Interviewees who worked on these issues professionally wanted birth parents to see themselves as parents and to know about their children's lives, and medical decision making is a part of that. As one advocate relayed, "Parents should be parenting. When you take that away from them, it weakens the connection and doesn't work toward reunification."72 A child welfare

\footnotetext{
${ }^{66}$ Adoption and Safe Families Act of 1997, Pub. L. No. 105-89, § 101(a)(B), 111 STAT. 2115, 2116 (1997).

${ }^{67}$ See OfF. OF Planning, Res. \& Evaluation, Admin. For Children \& FAMilies, No. 2011-27c, NSCAW II BASELINE REPORT: MALTREATMENT 4 (2011) http://www.acf.hhs.gov/sites/default/files/opre/nscaw2_maltreatment.pdf.

${ }_{68}^{6}$ Telephone Interview with S.A., foster parent in New York (August 5, 2015).

${ }^{69} I d$.

${ }^{70} \mathrm{Id}$

${ }^{71} I d$.

${ }^{72}$ In-person interview with C.A., child advocate in Pennsylvania (Aug. 12, 2015).
} 
agency supervisor concurred, saying that anecdotally, at least, parents who are involved with their children's medical care have more successful reunifications. ${ }^{73}$ If the foster care system wishes to support reunification, it should attempt to provide all possible opportunities for the birth parent to practice parenting. In practice, only some states inform or invite birth parents to attend medical appointments. ${ }^{74}$ A doctor in Michigan stated that while this did not happen as often as she would like, "parents of kids who are served by the foster care system are an integral part of their child's health and they should be involved at every single opportunity." ${ }^{, 75}$ Medical visits also provide an opportunity for birth parents to learn how to advocate for their children in a controlled environment.

Of course, there are also drawbacks to putting decision-making authority in the hands of an abusive or neglectful parent. Some parents have done terrible things to their children, and it may be hard to imagine how those parents can make positive decisions for those children. Some birth parents may resent their children or the children's needs, and refuse to consent to treatments as a part of what may be a larger pattern of emotional abuse. A mother refusing to quit smoking despite serious negative health effects for her asthmatic child may fall into that group. ${ }^{76}$ One foster parent reported that she purposefully did not tell the birth mom of one of her foster kids about certain medical appointments because she wanted to be able to talk openly with the doctor about things like fetal alcohol syndrome and possible shaken baby syndrome. The foster parent said, "It can be very difficult to talk openly with the doctor, to say, 'My child is experiencing this

\footnotetext{
${ }^{73}$ Telephone interview with K.N., child welfare agency supervisor in Idaho (Aug. 10, 2015).

${ }^{74}$ An Arkansas respondent wrote, "[T] he biological parents are never consulted for consent when the foster child needs medical help. They will be informed afterwards but not consulted."

${ }^{75}$ Telephone Interview with Dr. Jeanette Schied, child and adolescent psychiatrist in Michigan (June 18, 2015).

${ }^{76}$ Bahareh Keith \& Kimberly B. Handley, Is Parental Smoking Neglect of an Asthmatic Child? 16 VIRTUAL MENTOR 252, 252-56 (2014), http://journalofethics.ama-assn.org/2014/04/ecas3-1404.html (last accessed Nov. 2, 2015).
} 
due to prior physical trauma caused by the woman sitting right there." "77 It would be difficult to argue that the child's best medical interests are being served when the people who need to talk with the doctor cannot be open about the child's history.

Other parents may not understand their children's needs, due to cognitive impairments, addictions that interfere with their decision-making abilities, or a lack of education. One foster parent in Texas described conflict with the birth parents over a child's food intake. The foster mother said:

We had a little girl whose parents were addicts and were not educated, and something in their heads told them their little girl was lactose intolerant and she wasn't. It became a massive fight; they called into CPS because we gave her yogurt. $^{78}$

Researchers estimate that between forty and sixty percent of children of parents with intellectual disabilities have been removed from their homes. ${ }^{79}$ Parents with disabilities suffer from discrimination in court systems, and often have their children removed at birth or upon testimony about characteristics of people with similar disabilities rather than being based on the individual parent's observed parenting skills ${ }^{80}$ However, some parents do have disabilities that interfere with their abilities to parent, make medical decisions successfully, and conduct the required follow-up steps needed to ensure their children receive appropriate care. An adoptive parent described a troubling situation: "My adopted son's birthmother is very mentally ill and I was trying to be a good foster parent and let her hold the baby during the shots, and she dropped him." Another case had a happier ending, with one foster parent describing her efforts with "a

\footnotetext{
${ }^{77}$ Telephone Interview with S.B., foster parent and clinician in Washington, D.C. (Aug. 10, 2015).

${ }^{78}$ Telephone Interview with A.N., foster parent in Texas (Aug. 4, 2015).

${ }^{79}$ David McConnell \& Gwynneth Llewellyn. Stereotypes, parents with intellectual disability, and child protection. 24 J. SOC. WELFARE \& FAM. L. 297, 297 (2002).

${ }^{80}$ Elizabeth Lightfoot et. al., The Inclusion of Disability as a Condition for Termination of Parental Rights , 34 CHILD ABUSE \& NEGLECT 927, 929 (2010).

${ }^{81}$ Telephone Interview with S.A., foster and adoptive parent in New York (Aug. 5, 2015).
} 
case that involves some acuity issues on both parents' end." This foster mother conducted significant advocacy work to get two brothers diagnoses of autism and appropriate IEPs, and said that the birth mother was pleased to have someone else doing that work. "My impression is that it's a relief that she will get the children back with all of these educational and medical and mental health services already set up that will follow them home. ${ }^{, 82}$ In part due to her disability, the birth mother could not have done that work, but thanks to the foster parent having medical decision making rights while the children were in care, the birth mother actually benefitted.

Another reason not to insist upon state laws that would require birth parents to make all medical decisions is that it can be very difficult to reach these parents. Children suffer when parents who have legal rights to make medical decisions fail to respond to requests for permission. Some parents become uninvolved with their children after the children are removed from them, whether due to their own mental health or addiction issues or simply out of frustration at dealing with the system that has taken their children. "Vesting authority in an unavailable parent essentially results in a situation in which no one has authority to grant permission for a foster child's participation [in a medical treatment or procedure]." ${ }^{, 83}$ That means that the child welfare agency or the child's guardian ad litem must go in front of the judge in the case and ask for either a specific medical procedure or test to be performed or for someone else to be appointed medical decision maker instead of the parent, a process which can take considerable time. A foster parent in New Jersey described the process as taking six weeks with an uninvolved birthparent, saying, "My kids have never been unable to get the meds they needed,

\footnotetext{
${ }^{82}$ Telephone Interview with A.L., foster parent in New Jersey (Aug. 10, 2015).

${ }^{83}$ Sheryl L. Buske, Foster Children \& Pediatric Clinical Trials: Access without Protection is Not Enough, 14 VA. J. SOC. POL'Y \& L. 253, 297 (2007).
} 
so it's working, but they've had to wait and spiral downward." 84 There is little to no consistency between states in what "unavailable" means such that a court will order treatment.

This lack of consistency can be good or bad, depending on how much one wants a specific birth parent to be involved. In Delaware, “[u]nless parental rights have been terminated or legal guardianship transferred by the court, parents maintain the right to consent to any medical treatment, remain informed about their child's condition and wherever possible, participate in any medical decision making." ${ }^{85}$ While this appears to respect the authority of the birth parents, the phrase "wherever possible" allows the state to avoid contacting the birth parent. The caseworker is only required to make "reasonable efforts" to contact the birth parent. ${ }^{86}$ In practice, a Delaware pediatrician reported that she sees caseworkers putting in no effort at all. ${ }^{87}$ Survey respondents explained that for a birthparent to be deemed unavailable, a caseworker must try to reach the birthparent through calls, emails, mailing letters, and often visits to the birthparent's home or place of work.$^{88}$ Other respondents mentioned that caseworkers should be required to contact extended family. One respondent from Michigan wrote that caseworkers must check the jails and prisons via online databases, search on social media, make phone calls and

\footnotetext{
${ }^{84}$ Interview with T.G., foster parent in New Jersey (Aug. 4, 2015).

${ }^{85}$ Medical Consent and Health Care, Division of Family Servs._Policy Manual, March 2015, p53, http://kids.delaware.gov/policies/dfs/PolicyManual-04.16.2015.pdf (last accessed November 2, 2015) ${ }^{86} \mathrm{Id}$.

${ }^{87}$ Telephone Interview with C.Z., pediatrician in Delaware (Aug. 20, 2015).

${ }^{88}$ Survey respondents from 35 states responded to this long-form question, with answers that ranged from just the phrase "reasonable efforts" in Wyoming to descriptions of limited efforts in Pennsylvania ("I'm sure there is a legal standard, but in practice we just have to say we kinda-sorta tried to reach a parent. If their phone is off and no one answered the door after one attempt, we say they are unavailable. If an incarcerated father's prison case manager doesn't return our call promptly, we say we were unable to reach him.") to more zealous efforts in Minnesota ("Unavailable mean[s]- multiple attempts to call, text and email both biological parents; if the medical decision is not urgent- we will also send letters to last known address. [W] may also contact relatives who may also have means to connect with the bio parents to get them in contact with social services worker.").
} 
send letters to contact the parents. ${ }^{89}$ Another respondent, in Kansas, said, "[a]ll attempts must be made to contact the parent for as long as possible." ${ }^{90}$ Other respondents said much less effort was made to contact birth parents in their states, with only "reasonable" or "good faith" efforts being required and some states, like Louisiana, admitting to making "little to no effort" to include biological parents. $^{91}$

States that made little effort to contact birth parents often use signed permission forms to meet legal requirements without actually involving birth parents. "[M]any parents sign consent for routine health care at the time of placement, [and] caseworkers must locate and encourage parents to sign separate consents for other specific evaluations (e.g., mental health, developmental, or educational) or treatments, including any psychotropic medications." ${ }^{92}$ Written consent forms are usually written in complicated language, with "only $15 \%$ of the forms [in one study] in language as simple as Time magazine," and most forms are written at "an advanced undergraduate or graduate level." 93 Birth parents in many states are handed these forms and are asked or required to sign consents for the foster parent to take the child for medical treatment while the child is in state care. ${ }^{94}$ This process of form-signing makes almost a mockery of a parent's actual rights to consent, as the parent has no contact with the doctor at any point and is instead just being asked by the caseworker to give an overall consent to what is usually a broad range of specific decisions that need to be made.

\footnotetext{
${ }^{89}$ Survey respondent from Michigan, June 10, 2015, 17:44:24, in Strassburger, 2015, supra note 39. ${ }^{90}$ Survey respondent from Kansas, June 8, 2015, 9:01:42, in Strassburger, 2015, supra note 39.

${ }^{91}$ Survey respondents from Louisiana, June 2, 2015, 08:36:55, in Strassburger, 2015, supra note 39.

${ }_{92}$ Mark D. Simms et. al., Health Care Needs of Children in the Foster Care System, 106 PEDIATRICs 909, 914 (2000).

${ }^{93}$ Susan S. Manning \& Colleen E. Gaul, The Ethics of Informed Consent, 25 SOC. WORK IN HEALTH CARE 103, 113 (1997).

${ }^{94}$ KAN. AdMIN. REGS. § 28-4-808 (2012); N.H. DEP’T OF HEALTH \& HUM. SERVS., AN INCREDIBLE JOURNEY: A RESOURCE GUIDE TO ASSIST FAMILIES WITH FOSTER CARE ADOPTION \& PERMANENCY SUPPORTS 32, 36 (2014) http://www.dhhs.state.nh.us/dcyf/adoption/documents/foster-adopt-resourceguide.pdf; WIS. ADMIN. CODE DCF $§ 56.09$ (2015).
} 
Overall, birth parents retain the legal right to make medical decisions in most states, but in practice they are rarely the ones actively in control of the medical decisions affecting their children. As one interviewee stated, "The parents have rights at the convenience of the Department [of Children and Families]." 95 Instead of working with parents, states take over medical decisions, often delegating authority to caseworkers but sometimes keeping all power within higher-level administrators.

\section{B. States}

Federal and state laws are supposed to ensure that a child's basic medical needs are met. States have a parens patriae duty to protect incapacitated persons unable to act for themselves, and can appoint guardians for individuals in need of care. ${ }^{96}$ States already make some large medical decisions for all young people, ranging from compulsory immunizations to required newborn and school entry screenings. ${ }^{97}$ States make important medical decisions for adults, too, such as fluoridation of public water supplies and the quarantine of people suffering from communicable diseases. ${ }^{98}$ Despite public hysteria around vaccinations and Obamacare "death panels," 99 the idea of the state making medical decisions for the general public is generally accepted. Arguments in favor of the states making decisions for young people in the foster care system, then, find currency in that the state is accustomed to making decisions for vulnerable populations.

The idea of parens patriae protection, though, is a rough substitute for parents. Joseph

Goldstein wrote in 1977:

The legal system ... does not have the capacity to deal on an individual basis with the consequences of its decisions or to act with the deliberate speed required by a child's sense of time and essential to his well-being. Even if the law were not so incapacitated, there is no basis for assuming that the judgments of its decision makers about a particular child's needs would be any better than (or indeed as good as) judgments of his parents. ${ }^{100}$

\footnotetext{
${ }^{95}$ Telephone Interview with A.L., foster parent in New Jersey (Aug. 10, 2015).

${ }^{96}$ Peter Mosanyi, A Survey of State Guardianship Statutes: One Concept, Many Applications, 18 J. AM. ACAD. MATRIM. L. 253, 255 (2002)

${ }^{97}$ Robert Bennett, Allocation of Child Medical Care Decision-Making Authority: A Suggested Interest Analysis. 62 VA. L. REV. 285, 294-98 (1976).

${ }^{98} I d$. at $299-301$.

${ }^{99}$ Stanford T. Shulman, Of "Obamacare" and "CalifornImmunization," 44 PEDIATRIC ANNALS 292, 292 (2015); Stephen Stromberg, The GOP's Obamacare 'death panel' nonsense won't die, Washington Post (Mar. 22, 2015), https://www.washingtonpost.com/blogs/post-partisan/wp/2015/03/22/the-gopsobamacare-death-panel-nonsense-wont-die/ (last visited Jan. 20, 2016).

${ }^{100}$ Goldstein, supra note 55 , at 650 .
} 
Almost forty years later, family and dependency courts still operate under the idea that the state can effectively substitute its judgment for a parent's. A state substituting its judgment for a parent's with regard to medical decision making can mean a judge hypoethetically ordering a child to be placed in a residential treatment center, a caseworker telling a foster parent to take a child to a specific pediatrician, or a child welfare administrator determining whether a child should take Ritalin for ADHD or try behavioral interventions instead. This is particularly problematic with decisions of longterm consequence, such as HPV vaccine administration, IUDs versus the pill for a teenager, or potential masculinizing or feminizing surgeries for a child who has an intersex condition. ${ }^{101}$ The child will live with the results of that vaccine or lack thereof, that birth control choice, or that surgery, for the rest of his or her life, while the judge, caseworker, or child welfare administrator will move on to another case. The state may not share the same values or have the same deep knowledge of the child as a parent would, and so its determination of what is in the child's best interests would be different than a parent's.

States are slightly more hesitant to make medical decisions about psychotropic medications and non-routine care like the surgeries described above. In some states, psychotropic medication usage is considered important enough or perhaps controversial enough that decisions around it should be made by the birth parent or ordered specifically by a court. ${ }^{102}$ Only the "routine" care is left to the foster parent or caseworker. In Pennsylvania, for example, state code

\footnotetext{
${ }^{101}$ Ashley Huddleston, Intersex Children in Foster Care: Can the Government Elect Sex Assignment Surgery?, 22 J.L. \& POL'Y 957, 961, 980 (2014).

${ }^{102}$ Naylor et. al., supra note 37Error! Bookmark not defined. at 182 (Out of twenty-one states surveyed, "The most common method is for the legal guardians or parents to give consent $(n=8)$, followed by caseworkers $(n=7)$, and court order $(n=6) . ”)$
} 
allows local child welfare departments to make all routine medical decisions, giving examples of routine treatment that include "well baby visits, immunizations and treatment for ordinary illnesses. ${ }^{103}$ If half of all children in the foster care system have a diagnosable mental illness, ${ }^{104}$ one could argue that psychotropic medications are routine, and indeed, some states consider it to be so ${ }^{105} \mathrm{~A}$ child advocate in Pennsylvania stated that in her experience, it was always the child's foster parents or caseworker who determined whether the potential care was routine or not, rather than the caseworker. ${ }^{106}$ In one instance, a caseworker warned a birth mother that if she did not sign a consent form for the child to receive a specific psychotropic medication, the foster mother would no longer be able to handle the child, and the child would have to leave his foster home and go to some sort of institutional placement. ${ }^{107}$ In Wisconsin, an administrator reported, "If parents don't consent, there's a blanket court order." ${ }^{, 108}$ The consent form, then, is a sham. So even in areas in which power is supposed to be shared, it often is not, and the caseworker wields a great deal of power.

When a state makes medical decisions, caseworkers are most often the population rendering those decisions. Many caseworkers are very devoted to their work, but there are compelling reasons to prevent them from possessing medical decision making power. First, caseworkers often make important decisions with limited input from others and on a tight time

\footnotetext{
${ }^{103} 55$ Pa. Code $\S 3130.91(1)(i)$. See In re J.A., 107 A.3d 799, 819 (2015 Pa. Super. 3). (citing 55 Pa. Code $\S 3130.91(1)(\mathrm{ii})$, the Allegheny County Office of Children, Youth, and Families denied its ability to consent to non-routine medical treatment, arguing instead for the appointment of a separate medical decision maker).

${ }^{104}$ Burns, et al., supra note 21

${ }^{105}$ See e, e.g. ARK. DeP'T OF HUM. Servis., Foster PARENT HandBook, 31-38 (2013) http://humanservices.arkansas.gov/dcfs/DCFSpublications/PUB-030.pdf (last accessed Nov. 18, 2015); CAL. HeAlth \& SAFETY CODE § 1530.6 ; GCAC OF GA., Foster Parent Roles \& Responsibilities, http://www.gcacofgeorgia.com/FParent.aspx (last accessed Nov. 18, 2015). Survey data also indicates that in some states, psychotropics were held to a different standard, but not always.

${ }^{106}$ In-person interview with C.A., child advocate in Pennsylvania (Aug. 12, 2015).

${ }^{107}$ In re Lyle A., 830 N.Y.S.2d 486, 489-91 (Fam. Ct. 2006).

${ }^{108}$ Telephone Interview with J.B., child welfare administrator in Wisconsin (Aug. 10, 2015).
} 
schedule while juggling many other responsibilities, so medical decision making may be a lower priority ${ }^{109}$ One foster parent reported that she tried very hard to get a caseworker to come to several children's autism evaluations, but was unsuccessful. "I wanted them to see and feel what was going on, and I wanted them to give background information that I could not. We don't have the family's mental health background and health background, and I wanted the caseworker to give it." ${ }^{110}$ Next, while caseworkers are significantly more likely to know the child well than, for example, a judge or a state-level child welfare official, caseworkers are unlikely to have specialized training in nursing or other healthcare fields. ${ }^{111}$ An administrator in Georgia reported that if he were in charge, the caseworkers would not have the authority that they currently have to make medical decisions in his state. "I would not have DFACS workers as the authority. There's so much turnover, and they are so young and inexperienced. They can't make intelligent decisions." 112

Caseworkers and upper-level staff both face a great deal of pressure to find homes for the large numbers of children in their care, which provides an incentive to make the children on their caseloads as easy to care for as possible. ${ }^{113}$ Caseworkers may send children to residential treatment facilities simply because they have no foster homes or other facilities in which to put the children. ${ }^{114} \mathrm{~A}$ foster parent reported that in her area,

Often what happens is that if a kid has already moved three or four [times], the caseworker brings them somewhere so the caseworker can stop dealing

\footnotetext{
${ }^{109}$ Mekonnen, supra note 18, at 411.

${ }^{110}$ Telephone Interview with A.L., foster parent in New Jersey (Aug. 10, 2015).

${ }^{111}$ Many child welfare caseworkers have only bachelor's degrees. See CAREERS IN PSYCHOLOGY, START A CHILD WELFARE SOCIAL WORK CAREER, http://careersinpsychology.org/become-a-child-welfaresocial-worker/ (last visited Feb 20, 2016).

112 Telephone Interview with H.M., CEO, Family Ties Atlanta (Aug. 5, 2015).

${ }^{113}$ Chipungu \& Bent-Goodley, supra note 10, at 83-84 (discussing the high turnover of caseworkers, difficulties recruiting foster parents, and high needs of the children needing foster care placements).

${ }^{114}$ See Perlmutter \& Salisbury, supra note 30, at 734 n.47, 738.
} 
with it, so the kid shows up with a bottle [of pills]. I've had a lot of kids

show up with meds, and it wasn't to treat them, it was to keep them quiet. ${ }^{115}$

Caseworkers have significant motivations to make decisions that would make the caseworker's lives easier. It is well known that caseworkers at times intentionally fail to share information about children's needs if openness would reduce the likelihood of a foster home accepting that child, even if the silenece results in a child being in an inappropriate placement. ${ }^{116}$ Caseworkers need to find placements for children, and for the children to remain calm (or sedated) enough to maintain that placement. This places a finger on the scale such that any determination of whether a psychotropic medication is in a child's best interest is difficult for the caseworker to evaluate independently.

Using caseworkers as medical decision makers also means accepting a largely untrained and overworked population that changes jobs frequently. Turnover in child welfare services offices ranges between $20-40 \%$ annually, with some offices having $100 \%$ turnover in a single year. ${ }^{117}$ While the national recommendation for the number of ongoing cases assigned to a social worker is seventeen, a Louisiana foster parent reported that caseworkers in her area routinely handled seventy to eighty cases at a time. ${ }^{118}$ High caseloads coupled with high turnover lead to

\footnotetext{
${ }^{115}$ Telephone interview with V.C., foster parent and foster care alumna in Louisiana (Aug. 13, 2015).

${ }^{116}$ Dawn Teo, The 10 Most Surprising Things about Foster Care, Huffington Post (June 15, 2015), http://www.huffingtonpost.com/dawn-teo/the-10-most-surprising-things-about-fostercare_b_7058474.html (last visited Oct 23, 2016) ("To get a child placed into a foster family, some caseworkers will often say anything to get a child placed and will neglect to share important information.").

${ }^{117}$ Chipungu \& Bent-Goodley, supra note 10, at 83; Tonya M. Westbrook et. al., Improving Retention Among Public Child Welfare Workers, 30 ADMINISTRATION IN SOCIAL WORK 37, 38 (2006). (finding that filling a vacant position takes seven to thirteen weeks and there is a ten percent national vacancy rate). Id. ${ }^{118}$ CWLA Standards of Excellence for Services to Abused or Neglected Children and their Families, CWLA (1999), http://66.227.70.18/newsevents/news030304cwlacaseload.htm (last visited Jan 22, 2016); Telephone Interview with V.C., foster parent in Louisiana (Aug. 13, 2015). See also Telephone Interview with A.N., foster parent in Texas (Aug. 4, 2015) (stating that caseworkers in her area of Texas served thirty to forty families at a time).
} 
people unfamiliar with a child's case making decisions for the child. ${ }^{119}$ The Louisiana foster parent reported, "The caseworkers come for 10 minutes, maybe, a month.... Every three years they check to see if you have a fire extinguisher, but if you don't, they say, oh, you'll get one. They shrug. It's just whatever, whoever, is the kid still alive? Great." ${ }^{120}$ That foster parent also described how most caseworkers she had met never went past the living room, never seeing the children's bedrooms or if the children even have bedrooms. Even if a single caseworker stays on a child's case for the duration of a child's time in care, which is unusual, responsibility for medical decision making can shift during a child's time in care, so a child may still face inconsistency in care. A West Virginia caseworker told me that a county caseworker makes decisions when a child first enters care, then a foster care agency caseworker after the child is legally free for adoption, and then the family with whom the child has been living only after the adoption. ${ }^{121}$ Having frequent changes in who is doing the medical decision making results in underinformed caseworkers and much more difficulty in relationship-building.

Making medical decisions for youth in the foster care system is admittedly difficult. The American Academy of Pediatrics wrote that youth in foster care have "multiple, complex health care needs that demand a high level of medical sophistication . . . Except in unusual circumstances, caseworkers and foster parents do not possess the medical knowledge and familiarity with the intricacies of the health care system." ${ }^{122}$ Caseworkers do have clear legal authority to make medical decisions for youth in state care. ${ }^{123}$ However, despite the individual

\footnotetext{
${ }^{119}$ Simms et. al., supra note 92, at 914; Am. Acad. of Pediatrics, Committee on Early Childhood, Adoption, and Dependent Care, Health Care of Young Children in Foster Care, 109 PEDIATRICS 536, 536 (2002).

${ }^{120}$ Telephone Interview with V.C., foster parent in Louisiana (Aug. 13, 2015).

${ }^{121}$ Telephone Interview with A.P., caseworker in West Virginia (Aug. 4, 2015).

${ }^{122}$ See Fostering Health, supra note Error! Bookmark not defined., at 77.

${ }^{123}$ Caseworkers are representatives of state agencies; state laws and the survey agreed that agencies have the right to make at least medical decisions in every state.
} 
competence of some caseworkers, there are overwhelming reasons not to want caseworkers as medical decision makers. They have overwhelming caseloads and other responsibilities, high turnover and a general lack of medical knowledge, and they hold incentives to make decisions to make the caseworker's lives easier rather than in the best interests of the child.

\section{Foster Parents}

Foster parents are making at least some medical decisions in forty-two states and the District of Columbia. Arguments to allow foster parents to make medical decisions for the children in their care suggest that because the foster parents are the ones who see the children every day and make decisions about other aspect of daily life, ${ }^{124}$ they are therefore are best equipped to understand their medical needs. "[I]f you trust the foster parent enough to house the child, you should trust the [foster] parent to make medical decisions," said one foster parent. ${ }^{125}$ Another foster parent mentioned that one of her foster children had manageable behaviors in school, but being at her house in a family environment was very triggering for this child due to his history. ${ }^{126}$ The child could "hold it together" at a doctor's visit or a meeting with a social worker, but struggled in everyday family interactions that a caseworker would never observe. This foster parent lived in a state where she could not make decisions about psychotropic medications and so felt her experiences of the child's needs were dismissed and seen as unimportant, even though she saw a side of the child that others were not able to observe. ${ }^{127}$

There are strong reasons to empower foster parents to make medical decisions for the children in their care. Foster parenting is a difficult job and having the authority to make whatever decisions one needs to care for the child appropriately would make it easier. A foster

\footnotetext{
${ }^{124}$ See, e.g., Mo. Rev. Stat. $\S 210.566 .1$ (2016) ("Foster parents shall make decisions about the daily living concerns of the child").

${ }^{125}$ Telephone Interview with A.N., foster parent in Texas (August 4, 2015).

${ }^{126}$ Telephone Interview with T.G., foster parent in New Jersey (Aug. 4, 2015).

${ }^{127} \mathrm{Id}$.
} 
parent in Texas expressed how thankful she was to be allowed to make the day-to-day medical decisions. She said, "I think it's ridiculous that there are parts of the country where you can't get the kid amoxicillin for an ear infection while the kid is stuck there in pain." ${ }^{128}$ Foster parents, whether they have medical decision making authority or not, are expected to "provide for the day-to-day needs of children; respond to their emotional and behavioral needs appropriately; arrange and transport children to medical appointments, mental health counseling sessions, and court hearings; advocate on behalf of foster children with schools; and arrange visits with birth parents and caseworkers." ${ }^{\prime 29}$ Many foster parents find the experience of foster parenting and working with the state and private agencies to be "overwhelming and frustrating, causing many to leave foster parenting within the first year." ${ }^{130}$ Many foster parents view the opportunity to make medical decisions for their foster children as a sign of respect and recognition from caseworkers, something that is too often missing from their interactions. ${ }^{131}$ Medical decision making rights are not a reward to bestow upon the person who is working the hardest, but it is also possible that making foster parents lives easier and encouraging the retention of foster parents might be in the best interests of the foster children.

It would be in the best interests of youth in the foster care system for their appointments to be made more easily and for them to have the same access to care that a child outside of the system could have. Foster parents are often the people scheduling doctor's visits. ${ }^{132}$ They

\footnotetext{
${ }^{128}$ Telephone Interview with A.N., foster parent in Texas (August 4, 2015).

${ }^{129}$ Chipungu \& Bent-Goodley, supra note 10, at 83.

${ }^{130} \mathrm{Id}$. at 75 .

${ }^{131} \mathrm{Id}$. at 86.

${ }^{132}$ A few states codify the issue, see, e.g., IND. CODE § 31-28-3-2 (2015); LA. REV. STAT. § 40:1299.55 (2015); 10-148-16 ME. CODE R. § 9(G) (LexisNexis 2015); Va. Code Ann. §13.8.1 (2015). Others describe it in their foster parent handbooks, see, e.g. IOWA DEP'T OF HUM. SERVS., FOSTER PARENT HANDBOOK, September 200544 Comm. 33 https://dhs.iowa.gov/sites/default/files/comm33.pdf; WYO. DEP'T OF FAM. SERVS., FOSTER PARENT HANDBOOk 11 (2002), https://docs.google.com/file/d/0B-
} 
advocate for their foster children in many arenas, so adding medical issues would be logical. Foster parents are also the most likely people in a child's life to be available outside of regular business hours. One could order court appointed medical decision makers or county caseworkers to be on-call twenty-four hours a day, but then the likelihood of reaching someone who knows the child drops even further. Even planned events can be complicated, like the toddler in New Jersey who needed a medical consent for anesthesia before a scheduled 6AM surgery to insert ear tubes. The surgeon had accepted consent forms earlier, but the anesthesiologist would not, and state workers did not begin their shifts until 9AM. ${ }^{133}$ The foster parent was already taking the child to the early appointment, so would have been available to sign the form in the moment that it was needed. Such efficiencies ultimately would benefit the person receiving the care.

Naming foster parents as medical decision makers might also just acknowledge a power dynamic that already exists. Foster parents may in some cases use their day-to-day presence with the child and likely presence at appointments as a means to subvert whatever consent processes do exist, so authorizing foster parents to make decisions may simply regulate and make safe existing practices. ${ }^{134}$ Similarly, a foster parent in New Jersey described significant hostility from a birth parent who was refusing to allow a teenager access to therapy. ${ }^{135}$ This was within the birth parent's rights to do, but the foster parents finally said that without therapy being allowed, they would refuse to house the teen. ${ }^{136}$ In that way, foster parents were able to exert control even when legally the birth parent had the rights. Similarly, a foster parent described trying to get her

2EkWB4ILAQM1d1eFFTVjM1Ymc ("Foster parents are trusted to handle minor illnesses and accidents as they would for their own children.")

${ }^{133}$ Telephone Interview with T.G., foster parent in New Jersey (Aug. 4, 2015).

${ }^{134}$ Naylor et. al., supra note 37Error! Bookmark not defined., at 187 ("Foster parents, especially relatives of the child or adolescent for whom psychotropic medications are being recommended, may believe they are empowered to provide consent for treatment with psychotropic medications and may not inform the treating physician about the nature of the guardianship relationship.").

${ }^{135}$ Telephone Interview with A.L., foster parent in New Jersey (Aug. 10, 2015). ${ }^{136} \mathrm{Id}$. 
foster son onto a psychotropic drug when the child's birth mother had medical decision making rights: "There were times [the birth mother] was concerned about the meds, but her power was so little. I personally singlehandedly could talk her out of her dissent by being more intellectual." ${ }^{137}$ In this case, as is common, the foster parent was white and the birth parent black, making assertions of power even more complicated.

It is also important to note that not all foster parents want medical decision making rights or would use them well. Some may have no desire to advocate medically for children who may largely be seen as an income source ${ }^{138}$ Even excellent and highly skilled foster parents may not want this specific power. An advocate described a foster parent she knew who did not want to be the one to make medical decisions for the medically fragile child in her care, even though she was a retired nurse and understood the child's medical issues better than anyone else involved in the case.$^{139}$ This foster mother had a somewhat difficult relationship with the child's birth mother, and the foster mother worried that asserting any medical decision making rights could make the birth mother dislike and resent the foster mother more ${ }^{140}$ The vast majority of foster parents are white. A 2004 study showed that $75 \%$ of foster parents in Oklahoma were white, but only $44 \%$ percent of children in foster care in Oklahoma were white. ${ }^{141}$ In Oregon, $86 \%$ of foster

\footnotetext{
${ }^{137}$ Telephone Interview with T.G., foster parent in New Jersey (Aug. 4, 2015).

${ }^{138}$ Claudia Campbell \& Susan Whitelaw Downs. The Impact of Economic Incentives on Foster Parents, 61 SocIAL SERV. REV. 599 (1987); John Sepulvado \& Amelia Templeton, Militant Says Foster Children Were Pulled From His Home, OPB (Jan. 16, 2016), http://www .opb.org/news/series/burns-oregonstandoff-bundy-militia-news-updates/militant-says-foster-children-were-pulled-from-his-home-lavoyfinicum-burns-oregon/ (last visited Feb. 27, 2016). This should be on same page as EN.

${ }^{139}$ In-person interview with C.A., child advocate in Pennsylvania (Aug. 12, 2015).

${ }^{140} \mathrm{Id}$.

${ }^{141}$ Bill Grimm \& Julian Darwall, Foster Parents: Who Are They \& What Are Their Motivations?, 16 NAT'L CTR. FOR YOUTH L. no. 3, 2005, at http://youthlaw.org/publication/foster-parents-who-are-they-and-what-are-their-motivations/ (last visited Oct. 24, 2016); KIDSCOUNT Data Ctr., Children In Foster Care By Race And Hispanic Origin 2014: Oklahoma, http://datacenter.kidscount.org/data/tables/6246-children-in-foster-care-by-raceand-hispanic-
} 
parents were white, but only $57 \%$ of children in foster care were white. ${ }^{142}$. Empowering foster parents instead of birth parents would concentrate power in white hands.

Some foster parents can also act against the best interests of the child. Foster parents have been known to use the threat of rehoming children to exert significant influence upon doctors. In one case, a doctor testified that he "knew the foster mother was too rigid and felt regulating the child's behavior with medication would be easier and maybe beneficial for [the child] rather than moving her to yet another foster home." "143 Certain foster parents will "doctor-shop" until they get the result they want. Most states provide a higher level of funding for children with special needs, and psychotropic medications are one way to qualify children as special needs. The difference in funds can be dramatic, with a classification as "special needs" qualifying foster parents to receive hundreds of dollars more in foster care funds each month. ${ }^{144}$ As there are far fewer foster homes than children that need them, local agencies must work to maintain the existing placements even if the evidence for use of a medication is questionable or lacking. ${ }^{145}$

In sum, vesting foster parents with medical decision rights would benefit youths in foster care because foster parents see the children most and know them best, they are already performing other parenting tasks, and they are often making these decisions already. However, major concerns arise with the existence of foster parents who do not want that responsibility or

origin\#detailed/2/38/false/15/2638,2601,2600,2598,2603,2597,2602,1353/12992,12993 (last visited Oct. 24, 2016)

${ }^{142}$ Grimm \& Darwall, supra note 141; KIDSCOUNT Data Ctr., Children In Foster Care By Race And Hispanic Origin 2014: Oregon, http://datacenter.kidscount.org/data/tables/6246-children-in-foster-careby-race-and-hispanic-

origin\#detailed/2/39/false/15/2638,2601,2600,2598,2603,2597,2602,1353/12992,12993 (last visited Oct. 24, 2106).

${ }^{143}$ In re Martin F. \& Desiree L., 820 N.Y.S.2d 759, 767 (Fam. Ct. 2006).

${ }^{144}$ A. Rachel Camp, A Mistreated Epidemic: State \& Federal Failure to Adequately Regulate Psychotropic Medications Prescribed to Children in Foster Care, 83 TEMP. L. REV. 369, 386-87 (2011). 145 " $I d$. at 388. (finding that in 2004, there were over 500,000 children in state care, but only 153,000 licensed kinship and non-relative foster homes nationwide."). 
would not use it well, as well as the need to acknowledge the racial dynamics of putting more power over brown bodies in white hands. It is also important to recognize that youth may actually be best positioned to make at least some of their own decisions.

\section{Young People in Foster Care}

Young people in foster care have rights in some states to make decisions in certain areas

of their health care, ranging from reproductive health care to psychotropic medications. ${ }^{146}$ However, no state allows all young people to make all of their own medical decisions.

Caseworkers, judges, foster parents, and others routinely make decisions "in the child's best interest" that counteract the actual wishes of the child. ${ }^{147}$ Allowing youth to make their own decisions would empower them and make them more likely to cooperate with their treatment plans.

Age of consent varies, and can be individual, based on a judge's determination of maturity and thus emancipation, or statutory based on age. A majority of states allow minors in foster care to consent to contraceptive services; most of those states also allow minors not in foster care to make those decisions. ${ }^{148}$ Ages of consent for mental health treatment ranges from twelve in California and thirteen in Florida to sixteen in Washington D.C. and eighteen in Connecticut. ${ }^{149}$ Empowering youth at specific ages or stages rather than having a judge or state employee make individual determinations of a young person's capacity to make medical

\footnotetext{
${ }^{146}$ See maps in Section C., Data. See also, e.g., Younts v. St. Francis Hospital \& School of Nursing 469 P.2d 330, 337-38 (1970) (recognizing a mature minor exception in providing care to a minor withot parental consent in Kansas); TEX. FAM. CODE ANN. \$266.010 (2015) (describing how a court can authorize a foster child of at least 16 years of age to consent to all future medical care).

${ }^{147}$ Sheryl L. Buske, Foster Children \& Clinical Trials: Access Without Protection Is Not Enough, 14 VA. J. SOC. POL'Y \& L. 253, 294 (2007).

${ }^{148}$ Taylor I. Dudley, Bearing Injustice: Foster Care, Pregnancy Prevention, \& the Law, 28 BERKELEY J. GENDER L. \& JUST. 77, 112 (2013).

${ }^{149}$ Donald H. Stone, The Dangers of Psychotropic Medication for Mentally Ill Children: Where is the Child's Voice in Consenting to Medication?, 23 TEMP. POL.\& CIV. RTS. L. REV. 121, 136, n.141-n.144 (2013).
} 
decisions would lessen discrimination against youth with specific diagnoses or attributes, but a uniform age would disallow acknowledgement of especially mature minors. Just as judges use their own biases when evaluating parental fitness, youth are vulnerable to adults' visions of what the right choices are. ${ }^{150}$

Even rules granting youth legal rights to participate in decision making about their own cases are rarely enforced, such as Florida's Rules of Juvenile Procedure, which entitle children to be present at court hearings. ${ }^{151}$ A review of Florida's data revealed that fewer than one in five Florida children over the age of ten participated in the review hearings of their cases. ${ }^{152} \mathrm{~A}$ foster parent described the difficulty her foster daughter experienced when she was given medical decision making rights. The foster parent described her twelve-year-old foster daughter's first vaginal exam, which was attended by the child, the foster mother, the birth mother, the birth father, and a parent advocate. The doctor asked the child whom she wanted to be in the room during the exam, and that moment was very difficult emotionally for the child. According to the foster parent, the child froze and said nothing. ${ }^{153}$ Assigning decision making to young people places them in situations in which they are forced to show loyalty or disloyalty to their family members. Related, some medical decisions may be above teens' capacity; some people feel that the State should take a more active decision making role due to teens' lack of maturity. ${ }^{154}$

It is especially important to address the idea of young people making their own medical decisions after considering the number of young people in the foster care system who have no foster parent to advocate for them. Fifteen percent of youth in foster care in the United States, or

\footnotetext{
${ }^{150}$ Goldstein, supra note 55, at 661-62.

${ }^{151}$ Fla. R. Juv. P. 8.100(a).

${ }^{152}$ Perlmutter \& Salisbury, supra note 30 , at 752 n.141.

${ }^{153}$ Telephone Interview with S.A., foster parent in New York (Aug. 5, 2015).

${ }^{154}$ Amy T. Pedagno, Note, Who are the Parents? In Loco Parentis, Parent Patriae, \& Abortion DecisionMaking for Pregnant Girls in Foster Care, 10 AVE MARIA L. REV. 171, 200 (2011).
} 
over 62,000 young people, are in some sort of congregate (group) care setting. ${ }^{155}$ Some jurisdictions report that nearly two-thirds of their teenage clients are ending up in congregate care. ${ }^{156}$ Additionally, half of young people over the age of twelve in the foster care system nationally average eight months in congregate care settings. ${ }^{157}$ Young people in congregate care are approximately three times more likely to have a psychiatric diagnosis as young people placed in foster homes. ${ }^{158}$ The adult disability rights movement and psychiatric survivors movement might argue that these particular youth should be able to make all treatment decisions regardless of the outcome. ${ }^{159}$ However, the state's duty is to make decisions in the best interests of these youth, including those with significant immaturity or significant medical or psychiatric needs. Thus self-determination cannot be the answer for every young person.

Transgender and transsexual youth, in particular, would benefit from being trusted to make their own decisions. Many trans youth are forced out of both their homes and foster homes due to their gender identities and expressions. ${ }^{160}$ They end up living in congregate care due to few foster homes wanting teens, let alone LGBTQ teenagers. ${ }^{161}$ Many trans youth turn to the

${ }^{155}$ Congregate care includes supervised independent living facilities, group homes, juvenile detention facilities, and residential treatment centers, with staff having daily shifts instead of foster parents who are on duty twenty-four hours a day. Statistics on Foster Care, FOSTER CLUB, https://www.fosterclub.com/article/statistics-foster-care (last accessed Nov. 16. 2015).

${ }^{156}$ ANNIE E. CASEY Foundation, RightSIZING CONGREGATE CARE: A POWERFUL FIRST STEP IN TRANSFORMING CHILD WELFARE SYSTEMS 3 (2010).

${ }^{157} I d$.

${ }^{158}$ ADMINISTRATION FOR CHILDREN AND FAMILIES, A NATIONAL LOOK AT THE USE OF CONGREGATE CARE IN CHILD WELFARE II. (2015), http://www .acf.hhs.gov/sites/default/files/cb/cbcongregatecare _brief.pdf

${ }^{159}$ See generally UIC NAT'L RES. \& TRAINING CTR. ON PSYCHIATRIC DISABILITY \& THE SELFDETERMINATION KNOWLEDGE DEV. WORKGROUP, SELF-DETERMINATION FOR PEOPLE WITH PSYCHIATRIC DISABILITIES: AN ANNOTATED BIBLIOGRAPHY OF RESOURCES (2002), http://www.cmhsrp.uic.edu/download/uicnrtc-sdbib.pdf (arguing that people with psychiatric disabilities should be able to determine the course of their own treatment or if they choose to pursue treatment at all)

${ }^{160}$ Madelyn Freundlich \& Rosemary J. Avery, Gay and Lesbian Youth in Foster Care: Meeting their Placement and Service Needs, 17 J. GAY \& LESBIAN SOC. SERV. 39, 47 (2008).

${ }^{161} I d$. 
street to access hormones and sex work to get money to pay for the hormones. ${ }^{162}$ Some jurisdictions are beginning to allow youth more decision making power with regard to accessing trans-related care. Specifically, New York City used to insist that a young person have consent from a parent or guardian before beginning hormone therapy, ${ }^{163}$ but now has a process to allow child welfare services to override the parent's objections when the child has followed the appropriate steps and medical professionals agree on the treatment. ${ }^{164}$ When young people have the support of medical professionals, they can win decision making powers.

\section{E. Medical or Legal Professionals}

There are currently no states in which medical or legal professionals (other than judges) have the statutory right or right established by case law to make medical decisions for children in care. Rather, it is the duty of medical professionals to submit evidence to a decision-making party. ${ }^{165}$ Yet their advanced training and independent lenses may merit assigning some medical decisionmaking rights to medical or legal professionals.

${ }^{162}$ Gerald P Mallon, et. al., There's No Place Like Home: Achieving Safety, Permanency, and Well-Being for Lesbian and Gay Adolescents in Out-of-Home Care Settings, 81 CHILD WelfarE 407, 426-27 (2002); Madelyn Freundlich, Rosemary J. Avery, \& Deborah Padgett. Care or Scare: The Safety of Youth in Congregate Care in New York City, 31 Child Abuse \& Neglect 173, 180 (2007).

${ }^{163}$ The City of New York Administration for Children's Servs., Promoting a Safe \& Respectful Environment for Lesbian, Gay, Bisexual, Transgender (LGBTQ) Youth \& their Families Involved in the Child Welfare \& Juvenile Justice System, 22-23 (Policy 2012/01), http://www1.nyc.gov/assets/acs/pdf/policy_library_search/2012/C.pdf.

${ }^{164}$ See The City of New York Administration for Children's Servs., Non-Medicaid Reimbursable Treatments \& Services for Children in the Custody of the Administration for Children's Services, 7 (Policy \& Procedure 2014/xx), http://www1.nyc.gov/assets/acs/pdf/policy_library_search/2014/A.pdf; The City of New York Administration for Children's Servs., Medical Consents for Children in Foster Care, 11-12 (2014/08), http://www1.nyc.gov/assets/acs/pdf/policy_library_search/2014/E.pdf.

${ }^{165}$ See American College of Medical Quality, Policy 35: Medical Expert Consulting and Testifying, http://www.acmq.org/policies/policy35.pdf (last visited Oct. 24, 2016) ("In the role as a physician medical expert or consultant the physician must give an honest, comprehensive, and objective interpretation and representation of the medical facts based upon the applicable standard of care.") 
Some states do have people trained on medical issues within their child welfare agencies, and this can work very well. In New Jersey, a nurse visits the home every three months. ${ }^{166}$ While the nurse is located at the child welfare office, she is not employed by the child welfare office and so does not face a conflict of interest. ${ }^{167}$ The nurse becomes a connection to the rest of the child welfare office, to caseworkers who may be difficult to reach, and a resource for foster parents who may be struggling with a medical issue. ${ }^{168}$ Other foster care agencies contract with medical providers such that a doctor whose office is at the agency conducts the child's primary care. A caseworker who had experienced this type of arrangement reported this often worked well with regard to care coordination, and ensures that the doctor seeing the child is familiar with the experiences of children in the child welfare system. ${ }^{169}$ However, it could be very difficult for families who lived far from the agency and would otherwise have been able to utilize a more local or less busy doctor. ${ }^{170}$ Being required to see a particular doctor can be a significant gatekeeper preventing some children from accessing care. ${ }^{171}$ While doctors within agencies may or may not work, nurses who currently are acting just as connections to care are knowledgeable enough, could be independent enough, and might otherwise serve as excellent medical decision makers.

Existing efforts have ignored decision making but instead fund health care coordination for children in the child welfare system. A pediatrician described a pilot program in her county

\footnotetext{
${ }^{166}$ Telephone interview with T.G., foster parent in New Jersey (Aug. 4, 2015).

167 SARAh Zlotnick ET. Al, First Focus St. Pol'y AdVOC. \& REFORM CTR., IMPROVIng Child Well-Being: Strengthening Collaboration Between the Child Welfare \& Health Care Systems, 11 (2014); Child Health Program, Rutgers Francois-Xavier Bagnoud Ctr., http://fxbcenter.org/childwelfarenursing.html (last visited Oct. 24, 2016).

${ }^{168}$ Telephone interview with T.G., foster parent in New Jersey (Aug. 4, 2015).

169 Telephone interview with M.S., caseworker in New York (Aug. 5, 2015).

${ }^{170} I d$.

${ }^{171} I d$. "[T] $]$ here's a lot of places you can't have the child in therapy without the caseworker's consent or you have to use therapists who you are referred to by the agency, who are employed by the agency, or who have a contract with the agency. So they are big gatekeepers." Id.
} 
that funded a half-time medical social worker who worked with children's caseworkers, but funding was an issue. ${ }^{172}$ Care coordination competes with other priorities, including funding for the very health services that the children in question need. ${ }^{173}$ What collaboration does occur between child welfare and mental health systems "is often limited to contracts for front-end mental health services, such as screening and assessment, with little collaboration beyond these initial services." 174

A strong care coordinator could at least ensure that people know who should be making the decisions. Doctors and other medical professionals rarely know who should be giving informed consent for a child's care. ${ }^{175}$ New York City's recent guide to medical consents for youth in foster care is twenty-five pages, not including sample forms. ${ }^{176} \mathrm{In}$ such a complex system, doctors would need significant training to serve their clients well. A foster parent in Philadelphia reported that he had never been asked for documents at any medical appointments that would prove he was the person who should be making decisions for his foster child ${ }^{177} \mathrm{He}$ merely showed a letter from the foster care agency stating that the child was placed with him, and that was seen as sufficient. ${ }^{178}$ Under Pennsylvania law, though, the party with legal custody of the child can make only "ordinary medical decisions", and even those decisions are subject to

\footnotetext{
${ }^{172}$ Telephone interview with Dr. Z., pediatrician in Delaware (Aug. 20, 2015).

${ }^{173}$ U.S. GEN. ACCT. OFF., GAO-13-170, CHILD WelFARE: STATES USE FlEXIBLE FEDERAL FundS, But STRUGGLE TO MEET SERVICE NeEDS 18-20, 25-27 (2013), http://www.gao.gov/assets/660/651667.pdf.

${ }^{174}$ Camp, supra note 144 , at 384.

${ }^{175}$ Lisa Fisher-Jeffes, Charlotte Barton, \& Fiona Finlay, Clinicians' knowledge of informed consent, $33 \mathrm{~J}$. OF MED. ETHICS 181, 183 (2007).

${ }^{176}$ The City of New York Administration for Children's Servs., Medical Consents for Children in Foster Care, 11-12 (2014/08), available at http://www1.nyc.gov/assets/acs/pdf/policy_library_search/2014/E.pdf.

${ }^{177}$ Telephone interview with M.S., caseworker in New York (Aug. 5, 2015). ${ }^{178} I d$.
} 
the retained rights of the (birth) parents. ${ }^{179}$ It is fairly safe to assume that the doctors who see most children in foster care never receive any training about who should be consenting to the care of a child, and are apt to allow any party presenting himself as an authority to act as one. ${ }^{180}$

Some who would claim authority have no business doing so. Very few people have written about the issue of medical consents, but the proposal from the primary existing article on the topic is for states to have Psychotropic Review Boards, made up of community volunteers who:

could be charged with assessing the appropriateness and safety of prescribed medications, as well as assessing the agency's efforts towards obtaining other therapeutic interventions by volunteer physicians or psychiatrists. PRBs would be charged with looking holistically at the mental health needs of a particular child, identifying treatment options and treatment recommendations, and issuing reports to the court and the parties on the existing mental health care provided, including psychotropics prescribed, to a child in care. ${ }^{181}$

While an idealistic approach, it should not be enacted. Community volunteers should not be making medical decisions for vulnerable children in their free time. If not parents, children deserve someone with medical training, the ability to advocate for a specific child in appointments and with insurance, and the ability to make decisions quickly, without need for a committee to agree upon care.

One option is to use attorneys with specialized medical training. For many years, Allegheny County, Pennsylvania (Pittsburgh), had a system in which first independent attorneys and later attorneys affiliated with the county's guardian ad litem legal services could be appointed by the dependency court to act as educational and/or medical decision makers for

${ }^{179}$ PA. R. Juv. Ct.. P. § 1145; In re J.A., 107 A.3d 799, 814 (2015 Pa. Super. 3). See also In re J.J., 69 A.3d 724, 732-33 (2013) (addressing the limits of the parents' retained rights).

${ }^{180}$ Telephone interview with Dr. Z., a pediatrician in Delaware (August 20, 2015).

${ }^{181}$ Camp supra note 144 , at 400. 
youth in the child welfare system. ${ }^{182}$ At least in recent years, attorneys received specialized training about children's medical needs and had established relationships with local providers for more difficult questions. ${ }^{183}$ These medical decision makers were appointed to cases for children in which there was no appropriate biological or foster parent available to make educational or medical decisions for a child ${ }^{184}$ The legal authority for this was admittedly weak, using the theory that the dependency court could take any actions in the best interests of the child. ${ }^{185} \mathrm{In}$ 2015, the Pennsylvania Superior Court ruled that attorneys could no longer be appointed to these roles, and the biological parent, foster parent, or county child welfare agency would instead have to make the decisions. ${ }^{186}$ Unfortunately, the child welfare agency was resistant to being put in the role of medical decision maker. Child advocates I interviewed felt strongly that children's access to medical care was suffering under the new plan. ${ }^{187}$

One attorney reported that a child for whom she had previously served as medical decision maker was unable to see a therapist for over three months because nobody signed the paperwork or followed up after she her role in the case ended. ${ }^{188}$ The attorneys to whom I spoke felt that they were the most qualified to make medical decisions due to the specialized training they possessed, and "we had to tell [the child welfare agency] how to do their jobs." ${ }^{189}$ Contraindicators to attorneys serving as medical decision makers existed as well. Attorneys admitted

\footnotetext{
${ }^{182}$ I served as a court appointed educational and medical decision maker for youth in the child welfare system in Pennsylvania from 2012-2014.

${ }^{183}$ In-person interview with C.A., child advocate in Pennsylvania (Aug. 12, 2015).

${ }^{184}$ Id. See also Disability and Mental Health Summit 2016 Session Presenters: Cate Axtman, http://www.disabilitysummit.com/presenters/ (last visited Oct. 24, 2016) (describing Cate Axtman as "a court appointed medical decision maker for foster children who do not have an adult in their lives to make those decisions").

${ }^{185} 42$ Pa.C.S.A. § 6351(a)-(c), (e)-(g); In re J.A., 107 A.3d 799, 809-10 n.13 (2015 Pa. Super. 3).

${ }^{186}$ In re J.A., 107 A.3d at 817.

${ }^{187}$ In-person interview with C.A., child advocate in Pennsylvania (Aug. 12, 2015).

${ }^{188}$ In-person interview with C.P., child advocate in Pennsylvania (Aug. 12, 2015).

${ }^{189} \mathrm{Id}$.
} 
that even with their training, medical decision making was a difficult task because there were so many children, and it was difficult to know the children as well as the attorneys would have liked. ${ }^{190}$ A similar caveat could apply to a nurse in a medical decision making position. However, for children without birth or foster families who can advocate for them, medical and legal professionals are strong options.

\section{PART IV. CONCLUSIONS AND PROPOSALS}

Drawing conclusions about who should make medical decisions for young people in the foster care system is difficult, as there are benefits and drawbacks to each potential decision maker. Allowing birth parents to make medical decisions keeps power within their families and communities and may hasten reunification. Yet birth parents whose lives are in crisis or who have committed serious abuse or neglect against their children may be unable to make good decisions on their children's behalf. Foster parents already make many medical decisions and are well-situated to add medical decision making, but could be influenced by their own convenience or beliefs. Caseworkers have no time to add medical decision making to their many responsibilities, and have incentives to make decisions based on things other than the best interests of the child. Despite these drawbacks, caseworkers are currently the most common decision makers across the United States. Young people could make some of their own decisions, but some youth lack the maturity or health to perform their own medical decision making. Medical and legal professionals might do a good job, but would be the least likely to have ongoing knowledge of the child and the legal authority to permit them is unclear.

Determining which of those groups should be a default decision maker depends on the reader's personal weighing of advantages and disadvantages rather than any empirically correct answer.

\footnotetext{
${ }^{190}$ In-person interview with C.A., child advocate in Pennsylvania (Aug. 12, 2015) (stating that the
} maximum caseloads hovered around forty clients). 
The competing benefits and drawbacks point most strongly toward assigning birth parents as the default medical decision maker when a child enters care. A majority of young people who enter the foster care system are eventually reunified, ${ }^{191}$ so building decision-making capacity in those families is important. The birth parent should be encouraged to be actively involved with the caseworker assisting the birth parent in getting to appointments and understanding what is occurring at the appointments. Counties can incentivize birth parents to attend appointments by making attendance part of a case plan. New York and Idaho require birth parents to attend appointments as part of their case plans in their areas, and failure to attend appointments is conveyed to the judge and counted against the parent. ${ }^{192}$ Whether the parent has consented at one time should not be determinative of whether the parent consents at the new time, and a simple waiver of consent or form consent should not be seen as acceptable. ${ }^{193}$ The caseworker or other professional should provide "longitudinal oversight of a youth's care, monitoring of prescribing patterns, and consultative and educational services," since we know that birth parents may need help to coordinate health care for the child but may still be able to participate in decision making about that health care. ${ }^{194}$

If the birth parent proves to be inadequate at meeting the child's medical needs, then the rights should be transferred to a foster parent on a temporary basis. If there is no foster parent and the birth parent is unable to meet the child's needs, then rights should be transferred on a temporary basis to a court-appointed medical decision maker. Judges should evaluate medical decision making no later than at the one year mark. Over $75 \%$ of all family reunifications occur

\footnotetext{
${ }^{191}$ CHILD WELFARE INFO. GATEWAY. Foster CARE STATISTICS 2013 (2015), https://www.childwelfare.gov/pubPDFs/foster.pdf

${ }_{192}$ Telephone Interview with S.A., foster parent in New York (Aug. 5, 2015); Telephone Interview with K.N., child welfare agency supervisor in Idaho (Aug. 10, 2015).

${ }^{193}$ Manning \& Gaul, supra note 93, at 108.

${ }^{194}$ Naylor et.al., supra note 37, at 186-87.
} 
within the first year. ${ }^{195}$ Children who are still in care at the one year mark might benefit from an alternate medical decision maker. The Adoption and Safe Families Act (ASFA) calls for, in most cases, a termination of parental rights to be filed within 24 months of the child entering foster care.${ }^{196}$ At that point, the medical decision making rights should be transferred to the foster or pre-adoptive parents. If the child is not in a pre-adoptive home after 24 months, the judge should still note the time that has passed and appoint a foster parent or court-appointed medical decision maker. An agency's failure to find a child a permanent home should not result in that child suffering from the lack of an involved medical decision maker as well.

It is also key that there be consistency in the child's treatment plan, with clear lines of who is to make what decision, or preferably, who is to make all decisions. For one party to make decisions about whether or not to have a medical appointment, for example and a different party to coordinate the medical care can be confusing and even dangerous. ${ }^{197}$ States that attempt to make distinctions between "ordinary" or "routine" medical care versus "extraordinary" medical care ignore the realities of children with chronic health conditions. Take, as an example, a young person who had a genetic disorder that required regular liver checks with a specialist. ${ }^{198}$ These appointments were regular for him, but evaluating whether he should take the medication the specialist offered, despite its side effects, may not be. Group home staff members accompanied the patient to the quarterly appointments, as he had no foster parents and his birth parents were both deceased, but the patient moved between four different group homes within one year. The

\footnotetext{
${ }^{195}$ CHILD WELFARE INFO. GATEWAy, FAMILy REUNIFICATION: WHAT THE EVIDENCE SHOWS (U.S. Dep't of Health and Hum. Servs., Children's Bureau, 2011), https://www.childwelfare.gov/pubPDFs/family_reunification.pdf (last visited Feb. 21, 2016).

${ }^{196}$ Adoption and Safe Families Act of 1997, Pub. L. No. 105-89, § 103, 111 STAT. 2115, 2118 (1997).

${ }^{197}$ See, e.g., "An Act Improving Medical Decision-Making," S. 314, Mass. Legis. (2015) http://www.massmed.org/Advocacy/State-Advocacy/An-Act-Improving-Medical-DecisionMaking/\#.WA5tFjcpIqY (requiring multiple surrogate decisionmakers "to make reasonable efforts to reach a consensus" when there is no clear medical decision maker for a patient).

${ }^{198}$ In-person interview with C.P., child advocate in Pennsylvania (Aug. 12, 2015).
} 
person who should be the designated medical decision maker for youth in the foster care system should be determined on a case by case basis rather than have a team of people or various people assigned to handle different kinds of medications or treatments.

The logistics of health care delivery and medication management must also be addressed. Many interviewees complained about the lack of providers, particularly in rural areas, and for psychiatric concerns. ${ }^{199}$ Other issues in health care delivery include a lack of information sharing and "inconsistent medication beliefs or understanding among key figures. ${ }^{200}$ In many cases, the only person accompanying a child to a medical appointment is a transporter or case aide who knows nothing about the child or the child's medical history and is not authorized to make medical decisions for the child. ${ }^{201}$ All parties need to be on the same page in order to ensure that children in the foster care system do not suffer yet more trauma due to the failings of the adults in the system charged with protecting them.

We know, from the information presented earlier, that the current situation is failing. Too many children are receiving too many psychotropic drugs, and people who legally have the authority to make medical decisions for youth are often not the people actually making those decisions. State laws should be changed to reflect the birth parent as default medical decision maker, encouraging family reunification, but to have clear timelines at which the questions of who should be making decisions will need to be re-addressed and who might fill that role. Child welfare agencies should provide intensive care coordination services to help children and families, and judges should be open to appointing professionals for children who would

\footnotetext{
${ }^{199}$ Telephone Interview with H.M., CEO, Family Ties Atlanta (Aug. 5, 2015).

${ }^{200}$ Longhofer, Floersch, \& Okpych, supra note 47, at 401.

${ }^{201}$ Report of Gabriel Myers Work Group, FlA. DEP'T CHILD. \& FAM., 1,9 (Nov. 19, 2009), http://www.dcf.state.fl.us/initiatives/GMWorkgroup/docs/GabrielMyersWorkGroupReport082009Final.p df ("The value of psychiatric assessments for children in care is often limited by this lack of medical history and documentation of current behaviors.").
} 
otherwise have no one to advocate for them. Most of all, it is important to open a dialogue about these issues such that states can learn from one another. As one child advocate interviewed concluded, frustrated, "Who should make the decisions? That's a really hard question.".202

That is a hard question. This Article has raised that question, evaluated the possible decision-makers, and recommended an answer. The goal of this Article is to provide step toward reconciling the maze of conflicting laws and practices. It returns the emphasis to the "best interests of the child" and recognizes the often-conflicting roles of the birth parent, foster parent, and caseworker. The recommendation of the birth parent as the default decision-maker emphasizes the goal of family reunification, while acknowledging real timelines. We can do a better job serving youth in foster care than we currently do, and we should.

${ }^{202}$ In-person interview with C.P., child advocate in Pennsylvania (Aug. 12, 2015). 


\section{APPENDIX I: Qualtrics Survey Questions}

1. In which state are you located?

2. In your state of residence, who can have authority to make medical decisions?

Checkboxes (people can check more than 1 box)

biological parents, foster parents, caseworkers, guardian ad litems/attorneys, judges, the child, other but I know who it is, or I don't know

2a. If you chose "other, but I know who it is" who can have this authority in your state? (open box)

3. Who typically or most often makes medical decisions for youth in the child welfare system in your state?

Checkboxes (people can check more than 1 box)

biological parents, foster parents, caseworkers, guardian ad litems/attorneys, judges, the child, other but I know who it is, or I don't know

3a. If you chose "other, but I know who it is" who can have this authority in your state? (open box)

4. Are there exceptions to the answers above? For instance, there might be exceptions for certain medical procedures or for certain populations. Some examples of medical procedures might include surgeries, vaccinations, general physicals, sick visits, mental health services, reproductive health care, or other treatment and care options. Populations may include children in a foster home, children in a group home, children with private insurance through their birth parents, children over a certain age, or any other special circumstance. (open essay box) 5. If biological parents must be determined to be "unavailable" for someone else to make a medical decision, what does "unavailable" mean? What efforts must be made to reach the biological parent(s)?

6 . To the best of your knowledge, are policies and practices around medical decision making consistent across your state?

Checkboxes: Yes No Other

6a. If you chose "Other," please explain. (open box)

7. In your opinion, are youth in your area receiving the services they need, when they need them?

Checkboxes: Yes No Other

7a. If you chose "Other," please explain. (open box)

8. To the best of your knowledge, do youth in the foster care system in your area tend to keep the same doctor(s) as they move across placements, and does someone maintain consistent medical records for these youth?

Checkboxes: Yes No Other

8a. If you chose "Other," please explain.

9. To the best of your knowledge, is there someone whose job it is to maintain up-to-date medical records for youth in the foster care system in your area?

Checkboxes: Yes No Other

9a. If you chose "Other," please explain.(open box)

10. Are there areas where other states might learn from you? If so, what are these? (open box)

11. Are there areas you see a need for your jurisdiction to improve? If so, what are these? (open box) 
12. What is your professional role? Check all that apply.

Checkboxes (people can check more than 1 box)

Social worker, attorney, foster parent, guardian ad litem, administrator, judge, other

12 a - If you chose "other," how would you describe your professional role? (open box)

13. If you give me permission to use your name and/or title in my paper, what name and title would you prefer that I use for you? If you do not give permission, please just write "n/a".

14. Are you willing to be contacted for a short (approx $20 \mathrm{~min}$.) follow-up interview via phone or Skype? If so, please provide contact information for the best way to reach you. (open box)

15. Would you like to receive a copy of this paper when it is complete? If so, please provide your email address. Your email address will not be shared with anyone. (open box)

Appendix II. Sources of Law and Policy

\begin{tabular}{|c|c|}
\hline Alabama & ALA. CODE $\S 12-15-70$ \\
\hline Alaska & ALASKA STAT. $\S 47.10 .084 ;$ ALASKA STAT. $\S 25.20 .025$ \\
\hline Arizona & $\begin{array}{l}\text { ARIZ. REV. STAT. § 8-113; ARIZ. REV. STAT. § 8-201; ARIZ. REV. STAT. § 8- } \\
245 .\end{array}$ \\
\hline Arkansas & $\begin{array}{l}\text { ARK. CODE ANN. § 9-27-353; ARK. DEP'T OF HUM. SERVS., FOSTER PARENT } \\
\text { HANDBOOK PUB-30 (August 2013), } \\
\text { http://humanservices.arkansas.gov/dcfs/DCFSpublications/PUB-030.pdf } \\
\text { (last visited Oct. 26, 2016). }\end{array}$ \\
\hline California & $\begin{array}{l}\text { CAL. FAMILY CODE } \S \S 6550,6552,6924(\mathrm{~b}) \text {; CAL. HeALTH } \& \text { SAF. CODE } \S \\
\text { 1530.6; CAL. WelF. \& INST. CODE } \S 366.27(\mathrm{a}) ;\end{array}$ \\
\hline Colorado & $\begin{array}{l}\text { INNOVATIONS FOR CHILDREN, COLORADO FOSTER CARE HANDBOOK 14, 19, } \\
\text { 21-22 (2011), } \\
\text { https://imaginecolorado.org/documents/uploads/FosterCareHandbook92559 } \\
\text { 8.pdf (last visited Oct. 26, 2016). }\end{array}$ \\
\hline Connecticut & $\begin{array}{l}\text { Connecticut Foster Adopt, Legal: Legal Status of Children in DCF } \\
\text { Licensed Homes, in FOSTER CARE MANUAL, } \\
\text { http://www.ctfosteradopt.com/fosteradopt/cwp/view.asp?a=3795\&Q=5413 } \\
42 \text { Ch (last visited Oct. } 26,2016) \text {. }\end{array}$ \\
\hline Delaware & $\begin{array}{l}\text { Del. Code Ann. tit. 31, §5101 (2015); } \\
\text { 9-200-201 Del. Code Regs. } \$ 68 \text { (LexisNexis); DIVISION OF FAMILY SERVS., } \\
\text { POLICY MANUAL } 52 \text { (2016), http://kids.delaware.gov/policies/dfs/fs-policy- } \\
\text { manual.pdf }\end{array}$ \\
\hline Florida & $\begin{array}{l}\text { FLA. STAT. } \$ 39.0121 \text {; Charles G. Childress, The Rights of Children } \\
\text { Regarding Medical Treatment, } 25 \text { GPSOLO No. 3, } 2008 .\end{array}$ \\
\hline Georgia & $\begin{array}{l}\text { GA. CODE ANN. § 15-11-30 (2014); Foster Parent Roles \& } \\
\text { Responsibilities, GCAC GEORGIA, } \\
\text { http://www.gcacofgeorgia.com/FParent.aspx (last accessed 5/8/15). }\end{array}$ \\
\hline
\end{tabular}




\begin{tabular}{|c|c|}
\hline Hawaii & $\begin{array}{l}\text { HAW. REV. STAT. § 587A-15 (2015); Lynne Youmans, Rights of Foster } \\
\text { Parents, LEGAL AID SOCIETY OF HAWAII (September 2003), } \\
\text { http://ittakesanohana.org/wp-content/uploads/2011/02/Rights-of-Foster- } \\
\text { Parents.pdf (last visited May 8, 2015). }\end{array}$ \\
\hline Idaho & $\begin{array}{l}\text { IDAHO ADMIN. CODE r. 16.06.01-405.03, } 444 \text { (2016); When a child is } \\
\text { placed with you... A guide for relatives and kin caregivers, IDAHO DEP'T OF } \\
\text { HEALTH \& WELFARE 4-5, } \\
\text { http://healthandwelfare.idaho.gov/Portals/0/Children/AdoptionFoster/Guide } \\
\text { for_Relatives_and_Fictive_Kin.pdf (last visited Oct. } 24,2016 \text { ) }\end{array}$ \\
\hline Illinois & $\begin{array}{l}\text { 705 ILCS 405/2-11; Illinois Department of Children and Family Services, } \\
\text { Guidelines for the Utilization of Psychotropic Medications for Children in } \\
\text { Foster Care 1-2, } \\
\text { http://www.psych.uic.edu/csp/images/stories/medication_guidelines.pdf } \\
\text { (last accessed May 8, 2015); Center for Health Strategies, Models of } \\
\text { Agency Consent for Psychotropic Medications, } \\
\text { http://www.chcs.org/media/Models-of-Agency-Consent-TA- } \\
\text { Tool revised-NJ-langauge.pdf (last accessed May 8, 2015). }\end{array}$ \\
\hline Indiana & $\begin{array}{l}\text { Ind. Dep't of Child Services, Authorization for Health Care Services, in } \\
\text { CHILD WELFARE MANUAL (July 1, 2015), } \\
\text { http://www.in.gov/des/files/8.26_Authorization_for_Health_Care_Services. } \\
\text { pdf }\end{array}$ \\
\hline Iowa & $\begin{array}{l}\text { IOWA CODE } \$ 232.2 \text { (2016); IOWA DEP'T OF HUM. SERVS., FOSTER PARENT } \\
\text { HANDBOOK (2005) } 44 \text { Comm. } 33 \\
\text { https://dhs.iowa.gov/sites/default/files/comm33.pdf }\end{array}$ \\
\hline Kansas & KAN. STAT. ANN. § 38-2217; KAN. ADMIN. REGS. § 28-4-808 \\
\hline Kentucky & $\begin{array}{l}\text { Commonwealth of Kentucky Cabinet for Health and Family Services, } \\
\text { Department for Community Based Services, Authorization for Medical } \\
\text { Treatment, DPP-106A (R. 4/07), } \\
\text { http://chfs.ky.gov/NR/rdonlyres/D1E9D9ED-752D-4ADD-8677- } \\
\text { 42E9A0ACCEF1/0/DPP106AAuthorizationforMedicalTreatment.pdf (last } \\
\text { accessed May 8, 2015). }\end{array}$ \\
\hline
\end{tabular}




\begin{tabular}{|c|c|}
\hline Louisiana & $\begin{array}{l}\text { LA. STAT. ANN. \$ 40:1299.55; Office of Community Services, Foster Parent } \\
\text { Handbook } 32 \text { (Feb. 2006), } \\
\text { http://www.dss.state.la.us/assets/docs/searchable/OCS/fosterParenting/Fost } \\
\text { erParentHandbook0409.pdf (last accessed May 8, 2015). }\end{array}$ \\
\hline Maine & $\begin{array}{l}\text { ME. REV. STAT. ANN. tit. 22, } \S 4037,4063 \mathrm{~A}-\mathrm{B}, 4071(2015) \text {; } \\
\text { X-X-x Me. Code R. } \S 15-16 \text { (LexisNexis <year>); Maine Health Information } \\
\text { Management Association, General Rules for Release of Immunization } 3 \\
\text { http://www.mehima.org/legalmanual/Ch_1_General_Rules_April_2005.pdf } \\
\text { (last accessed June 2, 2015). }\end{array}$ \\
\hline Maryland & $\begin{array}{l}\text { C. \& J.P. § 3-824(b)(1); Maryland.gov Division of State Documents. Title } \\
\text { 07 DEPARTMENT OF HUM. RESOURCES } \\
\text { Subtitle 02 SOCIAL SERVICES ADMINISTRATION } \\
\text { Chapter } 11 \text { Out-of-Home Placement Program } \\
\text { http://www.dsd.state.md.us/comar/getfile.aspx?file=07.02.11.08.htm (last } \\
\text { accessed June 2, 2015). }\end{array}$ \\
\hline Massachusetts & $\begin{array}{l}\text { MASS. GEN. LAWS ch. 119, } \S \text { 23; MASS. DEP’T OF SOCIAL SERVS, } A \text { GUIDE } \\
\text { FOR FOSTER \& PREADOPTIVE PARENTS 12, 25-26, } 33 \\
\text { http://www.mass.gov/eohhs/docs/dcf/c-fp-ap-guide.pdf (last visited Oct. 24, } \\
\text { 2016). }\end{array}$ \\
\hline Michigan & $\begin{array}{l}\text { MicH. COMP. LAWS } § 722.124 a \text { (2016); Michigan Dep't of Health \& Hum. } \\
\text { Servs., Health Services for Foster Children, MicHIGAN CHILDREN's FOSTER } \\
\text { CARE MANUAL FOM 801, 17-19 (2016), } \\
\text { http://www.mfia.state.mi.us/OLMWEB/EX/FO/Public/FOM/801.pdf (last } \\
\text { visited Oct 26, 2016). }\end{array}$ \\
\hline Minnesota & $\begin{array}{l}\text { MINN. STAT. 260C.212 (2014); CHILDREN's LAW CENTER, KNOWING YOUR } \\
\text { RIGHTS, http://www.clcmn.org/wp-content/uploads/2009/07/CLC- } \\
\text { Knowing-Your-Rights.CLCMN_.2012.pdf (last visited Oct. 26, 2016); } \\
\text { Blue Earth County Hum. Services, Handbook for Foster Parents, } \\
\text { http://www.co.blue-earth.mn.us/DocumentCenter/View/425 (last visited } \\
\text { Oct. 26, 2016). }\end{array}$ \\
\hline Mississippi & $\begin{array}{l}\text { Miss. CODE ANN. § 41-41-3 (1) (2010); Mississippi Department of Hum. } \\
\text { Services, Division of Family \& Children Services, Mississippi Psychotropic } \\
\text { Medication Monitoring Plan for Children in Foster Care, available at } \\
\text { http://www.mdhs.state.ms.us/media/270523/Appendix-F-Psychotropic- } \\
\text { Plan-MS-Final.pdf (last accessed May 11, 2015). }\end{array}$ \\
\hline Missouri & $\begin{array}{l}\text { Missouri Child Welfare Manual, } \S 4 \text {, Ch. } 24.2, \text { Medical Information to be } \\
\text { Obtained when Child Enters Care, } \\
\text { http://dss.mo.gov/cd/info/cwmanual/section4/ch24/sec4ch24sub2.htm\#n242 } \\
\underline{3} \text { (last accessed Oct. } 26,2016) \text {. }\end{array}$ \\
\hline Montana & $\begin{array}{l}\text { CHILD \& FAM. SERVS. POLICY MANUAL: LEGAL PROCEDURE TEMPORARY } \\
\text { LEGAL CUSTODY p } 1 \text { of } 8 \text { 10/07, Number 302-3, } \\
\text { http://dphhs.mt.gov/Portals/85/cfsd/documents/cfsdmanual/302-3.pdf }\end{array}$ \\
\hline
\end{tabular}




\begin{tabular}{|c|c|}
\hline Nebraska & $\begin{array}{l}\text { NeB. REV. STAT. } \S 68-1212(1)(2015) ; 390 \text { NeB. AdMIN. CoDE } \S 7-001 \\
(2016) ; 390 \text { NeB. AdMIN. CoDE } \S 8-001.02 \text { (2016); In re Petition of } \\
\text { Anonymous 5, } 286 \text { Neb. } 640(2013) \text {. }\end{array}$ \\
\hline Nevada & $\begin{array}{l}\text { NEV. REV. STAT. } \$ 129.040 \text { (2016); NEV. REV. STAT. } \$ 432.525 \text { (2016); } \\
\text { Children's Advocacy Alliance, Policy Brief: Medical Consent (2015), } \\
\text { http://caanv.org/wp-content/uploads/2014/08/CAA-POLICY-BRIEF- } \\
\text { Medical-Consent_2015.pdf (last visited Oct. 26, 2016); Yesenia Amaro, } \\
\text { Medical consent at issue for ailing foster children, LAS VEGAS REV.-J. } \\
\text { (Sept. 26, 2014), http://www.reviewjournal.com/news/las-vegas/medical- } \\
\text { consent-issue-ailing-foster-children (last visited Oct. 26, 2016). }\end{array}$ \\
\hline $\begin{array}{l}\text { New } \\
\text { Hampshire }\end{array}$ & $\begin{array}{l}\text { Form } 2287 \text { - Psychotropic Medication Consent Request, N.H. DEP'T OF } \\
\text { HEALTH AND HUM. SERVS., Form } 2287 \text { (Jan. 2014), } \\
\text { http://www.dhhs.nh.gov/dcyf/adoption/documents/form2287- } \\
\text { psychmedconsent.pdf (last accessed May 13, 2015); Foster Care/Adoption } \\
\text { Program Division for Children, An Incredible Journey: A Resource Guide } \\
\text { to Assist Families with Foster Care Adoption and Permanency Supports, } \\
\text { N.H. DEP'T OF HEALTH AND HUM. SERVS. 36-37, } \\
\text { http://www.dhhs.nh.gov/dcyf/adoption/documents/foster-adopt-resource- } \\
\text { guide.pdf (last visited Oct. 26, 2016). }\end{array}$ \\
\hline New Jersey & $\begin{array}{l}\text { N.J. REV STAT § 9:6-8.86 (2013); Center for Health Strategies, Models of } \\
\text { Agency Consent for Psychotropic Medications, } \\
\text { http://www.chcs.org/media/Models-of-Agency-Consent-TA- } \\
\text { Tool revised-NJ-langauge.pdf (last accessed May 8, 2015); New Jersey } \\
\text { Dep't of Children \& Families, Resource Family Handbook 5, 13-14 (2015), } \\
\text { http://www.state.nj.us/njfosteradopt/ResourceFamilyHandbook.pdf (last } \\
\text { visited Oct. 26, 2016). }\end{array}$ \\
\hline New Mexico & N.M. STAT. ANN. § 32A-1-4; N.M. STAT. ANN. § 32A-6-14; \\
\hline New York & $\begin{array}{l}\text { N.Y. MENTAL HYG. LAW tit. E, } \$ 33.21 \text {; N.Y. PUB. HEALTH LAW Art. 25, } \\
\S 2504 \text {, NY Dept of Social Servs Admin Directive } 90 \text { ADM-21 (1990); NY } \\
\text { Dept of Social Servs Admin Directive } 11 \text { ADM-09 (2011); City of N. Y., } \\
\text { Administration for Children's Services, Policy and Procedure, 2014/08 } \\
\text { Medical Consents for Children in Foster Care (2014), } \\
\text { http://www1.nyc.gov/assets/acs/pdf/policy library search/2014/E.pdf (last } \\
\text { visited Oct. 26, 2016); NYS Office of Children \& Family Servs, "Medical } \\
\text { Consents," in WoRKING TOGETHER: HEALTH SERVICES FOR CHILDREN IN } \\
\text { FosTER CARE, } \\
\text { http://ocfs.ny.gov/main/sppd/health services/manual/Chapter\%206\%20Con } \\
\text { sent.pdf (last visited Oct. 26, 2016). }\end{array}$ \\
\hline $\begin{array}{l}\text { North } \\
\text { Carolina }\end{array}$ & N.C. GEN. STAT. § 7B-101 (2015); N.C. GEN. StAT. § 7B-903 (2015) \\
\hline North Dakota & $\begin{array}{l}\text { N.D. AdMIN. CODE } § 75-03-16-21 \text {; N. D. DEP'T OF HUM. SERVs., FosTER } \\
\text { PARENT HANDBOOK 76, https://www.nd.gov/dhs/info/pubs/docs/cfs/foster- }\end{array}$ \\
\hline
\end{tabular}




\begin{tabular}{|l|l|}
\hline & parent-handbook.pdf \\
\hline Ohio & $\begin{array}{l}\text { OHIO REV. CODE ANN. § 2151.04; DISABILITY RIGHTS OHIO, CHILDREN's } \\
\text { RIGHTS: THE RIGHTS OF CHILDREN AND THEIR FAMILIES WHO NEED OR ARE } \\
\text { RECEIVING COMMUNITY SERVICES, } \\
\text { http://www.disabilityrightsohio.org/childrens-rights-parents (2012) (last } \\
\text { accessed June 3, 2015). }\end{array}$ \\
\hline Oklahoma & $\begin{array}{l}\text { OKLA. STAT. ANn. tit. 10A, § 1-3-102; OKLA. ADMIN. CODE §413-020- } \\
0140\end{array}$ \\
\hline Oregon & OR. REV. STAT. §418.571;OR. ADMIN. R, 413-020-0140. \\
\hline
\end{tabular}




\begin{tabular}{|c|c|}
\hline Pennsylvania & $\begin{array}{l}42 \text { Pa.C.S. } § 6339(\text { b); } 42 \text { Pa.C.S.A. } \S 6351 \text { (g); } 42 \text { Pa.C.S. } \S 6352.1 ; 42 \\
\text { Pa.C.S.A. § 6357, In re J.A., } 107 \text { A.3d } 799 \text { (2015 Pa. Super. 3). }\end{array}$ \\
\hline Rhode Island & R.I. CODE R. 14-1-1000.0020 \\
\hline $\begin{array}{l}\text { South } \\
\text { Carolina }\end{array}$ & S.C. Code ANn. ReGs. 114-4980 \\
\hline South Dakota & S.D. CODIFIED LAWS $\S 26-7 \mathrm{~A}-42$ \\
\hline Tennessee & $\begin{array}{l}\text { Tenn. Code AnN. § 37-1-128 (West); TenN. Code AnN. § 37-1-140 } \\
\text { (West); Tenn. CodE ANN. § 37-1-128 (West); Op.Atty.Gen. No. 04-127, } \\
\text { Aug. 11, 2004, } 2004 \text { WL 1881176. }\end{array}$ \\
\hline Texas & $\begin{array}{l}\text { TEX. FAM. CODE ANN. § 5-E-266.004 (2015); Charles G. Childress, The } \\
\text { Rights of Children Regarding Medical Treatment, } 25 \text { GPSOLO No. 3, } 2008 .\end{array}$ \\
\hline Utah & $\begin{array}{l}\text { Utah's Division of Child and Family Services Out-of-Home Services, } \\
\text { Practice Guidelines, 303.5.1 (2015), } \\
\text { http://hspolicy.utah.gov/files/dcfs/DCFS\%20Practice\%20Guidelines/300- } \\
\text { \%20Out-of-Home\%20Services.pdf (last visited June 3, 2015). }\end{array}$ \\
\hline Vermont & $\begin{array}{l}\text { VT. STAT. ANN. tit. 33, §5102 (16)(A); VT. DEP’T FOR CHILDREN AND } \\
\text { FAMILIES, A GUIDE FOR FOSTER \& KINSHIP FOSTER FAMILIES IN VT. } 17 \\
\text { (2014), } \\
\text { http://dcf.vermont.gov/sites/dcf/files/pdf/fsd/pf/Resource_Guide_for_Foster } \\
\text { Parents.pdf (last visited June 3, 2015); Vt. Dep't for Children and } \\
\text { Families, Anti-Psychotic Medications for Children in the Care of DCF } \\
\text { Policy No. } 137 \text { (2014), } \\
\text { http://dcf.vermont.gov/sites/dcf/files/pdf/fsd/policies/137_Anti_Psychotic_ } \\
\text { Meds.pdf (last visited Oct. 26, 2016). }\end{array}$ \\
\hline Virginia & VA. CODE ANN. § 13.8.1; VA. CODE ANN. § 54.1-2969 \\
\hline Washington & $\begin{array}{l}\text { WASH. AdMIN. CODE } \S 388-148-0352 ; \text { WASH. REV. CODE ANN. } \S 13.32 \text { A.1 } \\
\text { (West) }\end{array}$ \\
\hline $\begin{array}{l}\text { Washington } \\
\text { DC }\end{array}$ & $\begin{array}{l}\text { Cheryl Durden, Child \& Family Services Agency, FY2014 Health Care } \\
\text { Oversight and Coordination Plan 11-12, 16-17 (2013), } \\
\text { http://cfsa.dc.gov/sites/default/files/dc/sites/cfsa/publication/attachments/D } \\
\text { C_CFSA_Health_Care_Coordination_Plan_2013.pdf (last visited Oct. 26, } \\
\text { 2016); Child \& Family Services Agency, Medical Consents Policy (Feb. } \\
\text { 15, 2015), } \\
\text { http://cfsa.dc.gov/sites/default/files/dc/sites/cfsa/publication/attachments/Pr } \\
\text { ogram\%20-\%20Medical\%20Consents\%20\%28Feb\%202015\%29_0.pdf } \\
\text { (last visited Oct. 26, 2016); FOSTER \& ADOPTIVE PARENT ADVOCACY } \\
\text { CENTER, FOSTER PARENT HEALTH ACCESS GUIDE } 12 \text { (2010), } \\
\text { http://www.dcfapac.org/pdfs/HealthGuideMay420101.pdf (last visited June } \\
\text { 4, 2015). }\end{array}$ \\
\hline
\end{tabular}




\begin{tabular}{|c|c|}
\hline West Virginia & $\begin{array}{l}\text { W. Va. Dep't of Health \& Hum. Resources, Policies 5.6, 5.6.3 } \\
\text { http://www.dhhr.wV.gov/bcf/policy/Documents/FC\%20Policy\%20- } \\
\text { \%20December\%202014\%20to\%20August\%202015.pdf (last visited Oct. } \\
\text { 26, 2016); W. VA. DEP’T OF HEALTH \& HUM. RESOURCES, } \\
\text { INFORMATION/INSTRUCTIONS REGARDING THE AFFIDAVIT FOR CONSENT FOR } \\
\text { HEALTH CARE FOR A MINOR, } \\
\text { http://www.wvdhhr.org/pdfs/affidavitconsentminor.pdf (last visited June 4, } \\
\text { 2015); }\end{array}$ \\
\hline Wisconsin & Wis. Admin. CODE DCF $\& 56.09$ \\
\hline Wyoming & WyO. STAT. ANN. § 14-3-420 Art. 4. \\
\hline
\end{tabular}

